IZA DP No. 8467

Do Wages Continue Increasing at Older Ages?

Evidence on the Wage Cushion in the Netherlands

Anja Deelen

Rob Euwals

September 2014 


\title{
Do Wages Continue Increasing at Older Ages? Evidence on the Wage Cushion in the Netherlands
}

\author{
Anja Deelen \\ $C P B$ \\ Rob Euwals \\ CPB, Netspar and IZA \\ Discussion Paper No. 8467 \\ September 2014 \\ IZA \\ P.O. Box 7240 \\ 53072 Bonn \\ Germany \\ Phone: +49-228-3894-0 \\ Fax: +49-228-3894-180 \\ E-mail: iza@iza.org
}

\begin{abstract}
Any opinions expressed here are those of the author(s) and not those of IZA. Research published in this series may include views on policy, but the institute itself takes no institutional policy positions. The IZA research network is committed to the IZA Guiding Principles of Research Integrity.

The Institute for the Study of Labor (IZA) in Bonn is a local and virtual international research center and a place of communication between science, politics and business. IZA is an independent nonprofit organization supported by Deutsche Post Foundation. The center is associated with the University of Bonn and offers a stimulating research environment through its international network, workshops and conferences, data service, project support, research visits and doctoral program. IZA engages in (i) original and internationally competitive research in all fields of labor economics, (ii) development of policy concepts, and (iii) dissemination of research results and concepts to the interested public.
\end{abstract}

IZA Discussion Papers often represent preliminary work and are circulated to encourage discussion. Citation of such a paper should account for its provisional character. A revised version may be available directly from the author. 


\section{ABSTRACT}

\section{Do Wages Continue Increasing at Older Ages? Evidence on the Wage Cushion in the Netherlands ${ }^{*}$}

In this study, we investigate the anatomy of older workers' wages. The central question is whether the wage cushion - i.e., the difference between actual wages and collectively agreed-upon (maximum) contractual wages - contributes to the fact that wages continue increasing at older ages. We follow the wages of individual workers in twenty-two sectors of industry in the Netherlands using administrative data for the period 2006-2010. In the public sector, we find no evidence of a wage cushion. Wage scale ceilings set in collective agreements are guiding for older workers' wages, and workers earning a contractual wage equal to a wage scale ceiling are not compensated with higher additional wages. In the private sector, we do find evidence of a wage cushion. Wage scale ceilings are less restrictive and workers earning a contractual wage exceeding the highest wage scale ceiling experience higher contractual wage growth. The private sector wage cushion enhances wage differentiation and allows for wages that continue increasing at older ages.

JEL Classification: $\quad \mathrm{C} 23, \mathrm{~J} 14, \mathrm{~J} 31$

Keywords: wages, economics of the elderly

Corresponding author:

Rob Euwals

CPB Netherlands Bureau for Economic Policy Analysis

P.O. Box 80510

2508 GM Den Haag

The Netherlands

E-mail: r.w.euwals@cpb.nl

\footnotetext{
* The authors thank Rob Alessie (Groningen University), Rik Dillingh (Dutch Ministry of Social Affairs and Employment), Marike Knoef (Leiden University), Bas van der Klaauw (Free University Amsterdam), Daniël van Vuuren (CPB) and an anonymous referee for useful comments and suggestions. Furthermore the authors thank Richard de Groot and Janneke Rijn for their research assistance.
} 


\section{Introduction}

The central research question in this study is whether the wage cushion is more important at older ages and contributes to the fact that wages continue increasing at older ages. ${ }^{1}$ Wages that continue increasing at older ages are perceived to be partly responsible for the unfavourable labour market opportunities of older workers in many countries, including the Netherlands (OECD, 2006, 2014). Wages that continue to increase with age hint at a wageproductivity gap at older ages, as empirical evidence suggests that productivity at best remains stable at older ages (Börsch-Supan and Weiss, 2008 and Van Ours and Stoeldraijer, 2011). Note that in cases in which productivity decreases with age, even a constant wage profile over age can be associated with a wage-productivity gap.

Empirical studies show that wages continue increasing at older ages in several European countries. On the basis of descriptive statistics from survey data, Table 3.3 of OECD (2006) concludes that wages continue increasing at older ages in Austria, Belgium, Finland, France, Italy, Spain and Switzerland. Applying panel data analysis to longitudinal administrative data, Zwick (2012) and Deelen (2012) find that wages continue increasing with experience at older ages in Germany and the Netherlands. These results are surprising because in continental European countries, wages are perceived to be determined largely by collective bargaining. The collective labour agreements generally include wage ceilings for the various wage scales in a sector of industry. In such a system, wages that increase with experience or tenure at older ages are not evident, unless the wage cushion plays an important role at older ages.

Several studies have assessed the incidence of wage cushions, but none of them associate the cushion with seniority wages. Cardoso and Portugal (2005) investigate how a system of collective bargaining can coexist with low unemployment and high wage flexibility in Portugal. They find that the wage cushion serves as a means to overcome the constraints imposed by collective bargaining. The results indicate that the wage cushion enhances the returns to workers and firm attributes. Jung and Schnabel (2011) find that more than forty per cent of German plants whose employees are covered by collective agreements pay wages above the level stipulated in the agreement, giving rise to a wage cushion. Their results

\footnotetext{
${ }^{1}$ The wage cushion, defined as the difference between actual wages and contractual wages as stipulated in collective labour agreements, consists of two parts: the first comprises additional wages paid above the contractual wage, and the second consists of the degree to which contractual wages exceed the highest wage scale ceiling, as stipulated in the collective labour agreement.
} 
indicate that the wage cushion varies with profits and labour shortages. While plants with single-employer agreements are less likely to have wage cushions, plants bound by multiemployer agreements seem to pay wage premiums to overcome the restrictions imposed by the centralized bargaining system in the western part of Germany. Our study investigates how a system of collectively-bargained wage scales can coexist with wages that continue increasing at older ages.

We investigate how older workers’ wages develop over time using administrative panel data on contractual and additional wages in twenty-two Dutch CLA (Collective Labour Agreement) sectors of industry. ${ }^{2}$ Our dataset is comprised of male workers between the ages of 23-63 in these sectors for the period 2006 - 2010. We merge our administrative data with wage scale data collected from collective labour agreements, such as the number of wage scales, the minimum and maximum wages per scale and the number of spinal points (the wage levels associated with standard increments along a wage scale). Combining actual wages with wage scale data enables us to analyse the effect of the wage scale system on actual wages.

First, wage regressions show how gross hourly wages develop after twenty or more years of potential experience and tenure. ${ }^{3}$ Using the results of similar regressions done with contractual hourly wages, we define an indicator for receiving a contractual wage that is equal to a collectively-agreed wage scale ceiling. We cannot tell with certainty whether a worker is receiving a contractual wage that is equal to the wage scale ceiling of a particular wage scale, as hourly wages are prone to measurement error, even in administrative data. Second, regressions show whether the likelihood of receiving a contractual wage at a wage scale ceiling —or, alternatively, exceeding the highest wage ceiling —increases with age and tenure. Third, wage regressions show whether workers receiving a contractual wage equal to a wage ceiling receive more in additional wages. Fourth, wage growth regressions show whether workers receiving a wage exceeding the highest wage ceiling experience more contractual wage growth.

\footnotetext{
${ }^{2}$ The contractual wage refers to the wage that is agreed upon in the labour contract. The additional wage refers to the sum of the incidental wage (performance-related, not part of the contract) and extra wage (a regular, extra wage component; for example, a thirteenth month of salary). Overtime pay is part of neither the contractual nor the additional wage.

${ }^{3}$ Potential experience is defined as age minus years of education, determined using the highest level of education attained, minus four years that represent the period before entering primary school. Time in the educational system cannot be less than 12 years because education is compulsory until age 16 .
} 
The results indicate that in the public sector, wage ceilings stipulated in collective agreements are guiding for older workers' wages. Wage scale ceilings are, however, less restrictive in the private sector. Older workers in the private sector more often receive a contractual wage exceeding the highest wage scale ceiling, resulting in a wage cushion in accordance with our definition. Workers earning a contractual wage equal to a wage scale ceiling do not receive more in additional wages. Workers earning a contractual wage exceeding the highest wage ceiling, however, experience higher contractual wage growth. In the private sector, this group of workers contributes to the steepness of the age-wage profile. Our study shows the limited role of the wage bargaining system in explaining wage growth at older ages. In the public sector, wage growth at older ages is limited by the system, as wage growth is actually restricted by the wage ceilings. In the private sector, wage growth at older ages is the result of the wage cushion.

The structure of this paper is as follows: the next section discusses the system of wage scales and wage bargaining as it prevails in the Netherlands, section 3 describes the empirical methodology of our analysis, section 4 presents descriptive statistics, section 5 presents the analysis of the wage cushion, section 6 gives the sensitivity analysis and section 7 concludes.

\section{Institutional setting}

Many sectors of industry in the Netherlands have a wage system that defines starting wages, wage increments and wage ceilings for the various wage scales in a sector. Wage negotiations and the resulting collective labour agreements generally contain an agreement on the general wage growth for all workers.

The twenty-two sectors of industry in this study are chosen on the basis of their size, measured as the number of total workers covered by a collective agreement. Almost all collective agreements cover over 100,000 workers, ${ }^{4}$ ensuring a large sample size in our empirical analysis. Note that we do not consider the total number of workers in a sector of industry because not all workers may be covered by the same agreement. The financial sector, for example, drops out of our selection, as most banks have their own firm-level agreement. The largest agreement in this sector therefore covers substantially fewer than 80,000 workers. We collect information on wage scales, wage floors, wage ceilings and spinal points for all twenty-two sectors (see appendix A for details).

\footnotetext{
${ }^{4}$ Except for the Coachworks industry (over 80,000 workers), public administration - region (over 13,000 workers), police and social work activities (each about 65,000 workers).
} 
$<$ INSERT TABLE 1 ABOUT HERE $>$

The sectors we consider in this study have a similar wage system. The transportation sector serves as an example (see Table 1). In 2006 and in the following years, the wage system has contained eight wage scales. Each job in the sector has wages according to one or more wage scales. Drivers of standard trucks may have wages according to wage scale 1, while drivers of special trucks (for example, of chemical products) may have wages according to wage scales 2, 3 and 4. Logistics planners will have wages according to higher wage scales, while managers are likely to be paid according to the highest wage scales. The lowest wage scales have five spinal points. Drivers in wage scale 1 will normally start at the wage floor and may have four wage increases during their career as a driver. The speed at which a driver climbs the ladder within a wage scale is at the discretion of the firm. The same holds for placing workers on a higher wage scale. Wage policy is likely to vary among firms, and it is also likely that worker performance and market circumstances play an important role. Note furthermore that the wage scales overlap. The ceiling of wage scale 1 , for example, is higher than starting wages in wage scales 2, 3 and 4.

\section{$<$ INSERT TABLE 2 ABOUT HERE $>$}

The wage systems of the various sectors differ with respect to wage floors, wage ceilings and the number of wage scales and spinal points. As Table 2 shows for the year 2006, the sectors have four (secondary education) to twenty (public administration at the municipality level) wage scales. The wage floors in the lowest wage scales vary from 1,173 (police) to 2,242 (secondary education) Euros per month. The wage ceilings in the lowest wage scales vary from 1,250 (cleaning) to 3,427 (secondary education) Euros. The lowest wages in primary and secondary education are high, as the sector requires a high level of education of its employees. The number of spinal points in the lowest wage scale is zero in sectors in which the wage ceiling is equal to the starting wage (retail sale, clothing and footwear, cleaning and home care). The education sector has the greatest number of spinal points in the lowest wage scale. In some sectors, wages are flexible within a wage scale (building construction, hotel and catering, temporary employment agencies and public administration at the regional level). The wage floors in the highest wage scales vary from 1,671 (clothing and footwear) to 6,164 (public administration at the municipality level) Euros. The wage ceilings in the highest wage scales vary from 1,764 (cleaning) to 8,311 (public administration at the regional 
level) Euros. The number of spinal points in the highest wage scales varies from six (clothing and footwear) to nineteen (social work activities). Note that the wage ceilings of the highest wage scales are substantially higher in the public sector than in the private sector. The wage scale system of the public sector includes all managerial jobs, while in the private sector this may not be the case.

Wage negotiations and collective labour agreements generally take the wage system as given. Consequently, negotiations between employers and unions generally lead to the same wage growth for all workers. Employers can reach agreement with one or more unions, and the Dutch Ministry of Social Affairs and Employment can extend the agreement to all workers in the sector, in cases in which these unions represent a large portion of the employees. Agreements are almost always extended; thus, the wage systems we consider here are in place for a large majority of workers.

Wage negotiations and collective bargaining may lead to differences in wage increases within a sector or to a reform of the wage system. In sectors such as hotel and catering and the police, the increase in the wage ceiling during the period from 2006 - 2010 was larger than the average wage increase. Furthermore, the wage ceilings of the highest wage scales in the home care sector increased substantially as it merged with the sector comprised of nursing homes for the elderly and disabled. Moreover, the wage system was reformed during our period of observation in the metal products and coachworks industries, as well as in the cleaning sector. Such reforms were partly responsible for newly-defined wage ceilings. The changes in the wage ceilings and wage systems have subsequently led to additional variation in the wage ceilings. Such variation will contribute to the identification of the impact of the wage ceilings on wage growth at older ages. We nevertheless decide not to exploit these changes and reforms as natural experiments due to the fact that the necessary assumption of exogeneity in these experiments is likely to be false, as the changes and reforms may be driven by labour market considerations. ${ }^{5}$

\section{Empirical methodology}

The central question is how wages can continue increasing at older ages in a wage system with wage bargaining and wage ceilings. We define an indicator $I_{i t}^{=}$for the likelihood of receiving a contractual wage that is equal to a wage ceiling of a wage scale for individual $i$ at

\footnotetext{
${ }^{5}$ In 1999, the government made a mistake in wage negotiations for the police, leading to higher wage growth than intended for police officers in certain wage scales. This would be a true natural experiment.
} 
time $t$. Remember that all sectors have a wage system with more than one wage scale. Furthermore, we will define an indicator $I_{i t}^{+}$for the likelihood of receiving a contractual wage exceeding the highest wage ceiling in a sector. The indicators will be used to answer a number of empirical questions to unravel the puzzle of wages that continue increasing at older ages:

1. Does the likelihood of being at a wage ceiling continue increasing at older ages? Or alternatively, does the likelihood of receiving a contractual wage above the highest wage ceiling continue increasing at older ages?

2. Do workers receiving a contractual wage that is equal to a wage ceiling receive more in additional wages?

3. Do workers that receive a contractual wage above the highest wage ceiling experience more contractual wage growth?

A positive answer to the first part of the first question may be interpreted as evidence against wages that continue increasing at older ages. Wages paid above the wage ceiling, however, leave room for wages that continue increasing at older ages. The second and third questions also leave room for wages to continue increasing at older ages. Each question will be answered using empirical models for (1) the indicators, (2) additional wages and (3) wage growth. The first empirical model will explain the indicators from individual demographic and educational characteristics, while the second and third empirical models will also include the indicators as explanatory variables. Note that both the second part of the first question and the third question refer to parts of the wage cushion (see footnote 1).

The empirical complication to answering the questions is that we do not observe the wage scale of individual workers. In other words, we first need to define measures for the indicators of being paid the maximum on a wage scale and being paid more than the highest wage ceiling. To do this, the section defines an empirical model with specification and measurement errors for wages. The model is used to determine the workers' wages vis-à-vis the ceilings in the wage scales of the sectors of industry concerned. We will propose measures for indicators $I_{i t}^{=}$and $I_{i t}^{+}$. In addition, the empirical model for wages is used to check whether wages continue increasing with experience or tenure at older ages-i.e., whether the results of Zwick (2012) and Deelen (2012) are reproduced with these data. 
We follow contractual and additional wages of male workers in twenty-two large Dutch sectors of industry over the period from 2006 - 2010, using administrative data from the Social Statistical Database of Statistics Netherlands. ${ }^{6}$ The sectors of industry are chosen such that all workers are covered by the same collective agreement (see also Section 2). Individual, contractual wages are compared to wage ceilings to determine the 'likelihood' of receiving a contractual wage that is equal to the ceiling of a wage scale. ${ }^{7}$ We also determine the likelihood of receiving a contractual wage exceeding the highest wage ceiling in a sector of industry. Our data sources do not indicate with certainty whether or not a worker receives a wage equal to a wage ceiling for two reasons. First, wage assessment contains measurement error, even in the case of administrative data. For example, information on working hours is used to calculate full-time wages, and this information may contain measurement error. Second, we do not observe the wage scales of individual workers. Since adjacent wage scales may be partly overlapping (see Table 1 for an example), a worker receiving a contractual wage equal to a wage ceiling may not be at this ceiling, as he may receive a wage according to a higher adjacent wage scale. We assume a worker is at a ceiling when (1) his wage is close to a wage ceiling of a wage scale and (2) his contractual wage growth is close to the contractual wage growth stipulated in the collective labour agreement.

Define $W_{i t}$ as the observed wage of individual $i$ at time $t$. All wage equations will be sector-specific whereby we suppress the sector index. Assume the following random effects wage equation:

$W_{i t}=X_{i t}^{\prime} \beta+\omega_{i}+\omega_{i t}$

with $\omega_{i}$ and $\omega_{i t}$ individual job-specific and idiosyncratic error terms. Individuals with more than one job during our period of observation have more than one draw from the distribution of the individual job-specific error terms, but for notational convenience we suppress the job

\footnotetext{
${ }^{6}$ The Social Statistical Database of Statistics Netherlands actually consists of several databases that can be merged; our main datasets ('polisikvbus' and 'polisikobus') contain administrative data from employers, the tax authority and social security organisation, UWV. Employers provide a code for the collective labour agreement under which the workers operate, which is used as a key variable to merge the wage scale data obtained from the collective labour agreements (see Appendix A). In addition, we used a dataset containing data from municipal base administrations (GBA) as well as data on the level of education of workers.

${ }^{7}$ We determine an indicator for the probability of receiving a contractual wage equal to the highest wage ceiling; we cannot determine the true probability, as we do not observe the salary scale of a worker.
} 
index. The vector $X_{i t}$ contains standard demographic and human capital variables including (potential) labour market experience and tenure. The vector $\beta$ contains parameters. The error terms are assumed to be independent and identically distributed. We will allow the individual specific wage equation error $\omega_{i}$ to be correlated with tenure and potential experience. The model is still to be interpreted as a random effects model, although because of the allowed correlation with some exogenous variables it contains elements of a fixed effects model.

The estimation model will be used for two purposes. First, we will investigate whether the gross hourly wage continues increasing with experience or tenure at older ages. We instrument experience with the deviation between experience and the individual job average of experience, and tenure with the deviation between tenure and the individual job average of tenure (Altonji and Shakotko, 1987, Abraham and Farber, 1987). As this method does not deal with unobserved, match-specific characteristics, the results underestimate the true effect of tenure and experience on wages (Altonji and Williams, 2005). Dustmann and Meghir (2005) deal with match-specific characteristics and Buchinsky et al. (2010) deal with endogenous mobility, but such issues are beyond the scope of this study.

Second, we apply the model to gross hourly contractual wages since the second purpose of the model is to use the results to calculate an indicator of the likelihood that an individual worker receives a contractual wage at the wage ceiling of a wage scale. Note the error terms $\omega_{i}$ and $\omega_{i t}$ contain two types of errors: measurement error and specification error. Define $\varepsilon_{i}$ and $\varepsilon_{i t}$ as individual specific and idiosyncratic measurement error, respectively. The distribution of these error terms cannot be identified from equation (1), but we know the variances of measurement error $\left(\sigma_{\varepsilon 1}^{2}, \sigma_{\varepsilon 2}^{2}\right)$ are smaller than or equal to the variances of the estimated model for the contractual wages $\left(\sigma_{\omega 1}^{2}, \sigma_{\omega 2}^{2}\right)$.

Define $W_{i t}^{*}$ as the true (unobserved) contractual wage of individual $i$ at time $t$. Two conditions must be met for an individual worker to receive a true contractual wage equal to the wage ceiling $W_{j}^{\max }$ of wage scale $j$ : (1) the wage must be equal to the wage ceiling of wage scale $j$, and (2) the contractual wage growth must be equal to the contractual wage growth stipulated in the collective labour agreement (CLA): which for reasons of convenience we assume it to be zero here, but we do take it into account in the empirical exercise. We implement condition (1) as follows:

$P\left(W_{i t}^{*}=W_{j}^{\max }\right)=P\left(\left(W_{i t}-W_{j}^{\max }\right)-\delta h_{1}<\varepsilon_{i t}^{T} \leq\left(W_{i t}-W_{j}^{\max }\right)+\delta h_{1}\right)$

with $\varepsilon_{i t}^{T}=\varepsilon_{i}+\varepsilon_{i t} \sim N\left(0,\left(\gamma_{1} \sigma_{\omega 1}^{2}+\gamma_{2} \sigma_{\omega 2}^{2}\right)\right)$ 
whereby we define $h_{1}$ as half of the average contractual wage increment in a sector of industry when a worker moves to the next spinal point on his wage scale. Two sensitivity parameters are important in determining the probability of receiving a contractual wage equal to the maximum wage level of a job: $\delta$ determines how large the bandwidth of the wage system is and $\gamma_{1}$ and $\gamma_{2}$ determine which portion of the error term of the empirical wage model is due to measurement error. Next, we implement condition (2) as follows:

$P\left(W_{i t}^{*}-W_{i t-1}^{*}=0\right)=P\left(\left(W_{i t}-W_{i t-1}\right)-2 \delta h_{2}<\varepsilon_{i t}^{U} \leq\left(W_{i t}-W_{i t-1}\right)+2 \delta h_{2}\right)$

with $\varepsilon_{i t}^{U}=\varepsilon_{i t}-\varepsilon_{i t-1} \sim N\left(0,2 \gamma_{2} \sigma_{\omega 2}^{2}\right)$.

whereby we define $h_{2}$ as half of the average year-to-year change in contractual wages at a particular spinal point of the wage scale in a sector of industry. In order to calculate the joint probability of both conditions one needs to take into account the fact that the error terms $\left(\varepsilon_{i t}^{T}, \varepsilon_{i t}^{U}\right)$ are correlated as both contain error term $\varepsilon_{i t}$ (see Appendix B for details). For the base case we assume the sensitivity parameters $\delta=1, \gamma_{1}=0.01$ and $\gamma_{2}=0.05$. This implies that we assume wages are equal to a wage scale ceiling in cases in which they are less than half of a wage increment from the ceiling, and in equation (2) we assume one percent of the individual error terms and five percent of the idiosyncratic error terms of the empirical model to be due to measurement error. We will provide sensitive analyses for the choices of parameters $\left(\delta, \gamma_{1}, \gamma_{2}\right)$.

We define indicator $I_{i t}^{\overline{\bar{t}}}$ as the joint probability of receiving a contractual wage that is equal to a wage ceiling of a wage scale and a contractual wage growth that is equal to zero. We define indicator $I_{i t}^{+}$as the probability of receiving a contractual wage exceeding the highest wage ceiling in a sector (Appendix B). Note that although these indicators are defined as probabilities, they should not be interpreted as true probabilities of being at a wage ceiling or being paid above the wage ceiling as we do not observe this directly. In other words, they remain to be interpreted as indicators. These indicators are used to answer the three empirical questions defined at the beginning of this section.

\section{Descriptive statistics}

In the public sector, contractual wage levels appear to be fairly close to the exact wage levels stipulated in the collective labour agreement, while in the private sector the CLA-wage scheme seems to be less of a constraint on contractual wages. The histograms in Figure 1, 
displaying the frequencies of contractual wages from 2000-2500 Euros per month (with a bin width of 10 Euros) for the basic metal industry and the state public administration, provide illustrative examples. Wage scale ceilings are clearly recognizable as spikes in the contractual wage distribution of the public administration, while this is not the case for the basic metal industry. It is unclear whether this reflects true deviation from the wage scale system or measurement error. For this reason, it is difficult to assess whether an individual worker's contractual wage equals the CLA-wage ceiling in the private sector. Therefore, the contractual wage growth also has to be taken into account in order to assess whether a worker's wage is at the ceiling of the wage scale.

\section{$<$ INSERT FIGURE 1 ABOUT HERE $>$}

Table 3 shows the CLA-sample to be representative of the total population of men. The table presents mean, median and standard deviation of main characteristics for the total population of male workers, as well as for male workers in the sample of industries for which CLA-data are collected. Demographic characteristics such as age are similar in both datasets. Potential experience and tenure are only slightly higher in the CLA-sample. In the sample, large firms (>500 employees) are slightly overrepresented, at the expense of small firms. About eighty per cent of the workers operate on a full-time contract in both datasets. Highereducated individuals seem to be slightly underrepresented in the CLA-sample.

The major difference between the full dataset and the CLA-sample concerns the wages $^{8}$. Contractual wages are about 16 percent lower in the CLA-dataset compared to the full dataset, while median wages are 12 percent lower. The average additional wage is also significantly lower in the CLA-sample. This is mainly caused by differences in the upper part of the distribution, since the median is fairly similar. The main reason for the deviations in wages is that high-paying sectors such as financial services, ICT and professional services are not included in the CLA-sample.

$<$ INSERT TABLE 3 ABOUT HERE $>$

\section{$<$ INSERT TABLE 4 ABOUT HERE $>$}

\footnotetext{
${ }^{8}$ In order to prevent that unrealistically low wages or exceptionally high wages influence the outcomes, real hourly wages below 6 Euro’s and above 200 Euro’s are excluded from the data throughout the analysis.
} 
Table 4 focuses on the development of average wages over age ranges. The first four columns, displaying the average contractual wage by industry, show a steep increase between ages 23-34 and ages 35-44. In age ranges 35-44 and 45-54, private sector wages on average increase by 7 per cent, compared to 12 per cent in the public sector. Between the ages of 4554 and 55-64, average contractual wages decrease by 5 percent in the private sector, while on average remaining constant in the public sector. Cohort effects may play a role here. The second set of four columns in Table 4 displays the average additional wage, which is the sum of the incidental wage and extra salary, over age ranges. Again, there is a clear but flattening increase up to ages 45-54. This pattern is much more pronounced in the private than in the public sector. Between age groups 45-54 and 55-64, average additional wages decrease by only 2 percent in the private sector and by 11 percent in the public sector. Demonstrating the opposite of the patterns for contractual wages, which hardly decrease at older ages in the public sector but do decrease in the private sector, additional wages typically decrease in the public sector but remain at the same level in the private sector. The level of additional wages, relative to that of contractual wages, is higher in the public sector (9 percent for age group $35-44)$ than in the private sector (6 percent), probably because a thirteenth month of salary is common in the public sector. Additionally, sectors that probably have high productivityrelated pay, such as financial services, ICT and professional services, are not included in the CLA-sample. Note that the descriptive statistics do not take into account all kinds of composition effects such as level of education.

The first four columns of Table 5, presenting the incidence of additional wages, show that in the public sector, it is common for workers to receive additional wages, while in the private sector, the incidence varies widely across sectors of industry. The second set of four columns shows the incidence of wages exceeding the highest wage scale ceiling. While wages exceeding the wage ceiling of the highest scale are rare in the public sector, probably because wages in the highest wage scales are high, it is common in the private sector where the wages in the highest wage scales are relatively low in some sectors of industry. Evidently, wage ceilings stipulated in collective agreements do not serve as a cap on wages in the private sector and probably not all managerial jobs are included in the system. The incidence increases between ages 23-34 and ages 35-44 and remains constant over older age ranges. 
Table 6 presents descriptive statistics on the indicators discussed in Section 3 for the private- and public-sector CLA's as a group (information per CLA-industry can be found in the Appendix, Table C1). Indicator I1 (reflecting the proximity of the individual contractual wage to the wage ceiling of a wage scale) is higher in the public sector than in the private sector. This holds especially true for public administration and may be related to the fact that the contractual wage distribution of public administration tends to be clustered around scale ceilings. Also, indicator I2 (reflecting the proximity of contractual wage growth to collectively-agreed wage growth) is on average higher in the public sector, indicating that the public sector has a larger share of workers at a scale ceiling than the private sector. Indicator $\mathrm{I}^{=}$(the indicator of the contractual wage being at the wage ceiling of a wage scale) combines both sources of information. Indicator $\mathrm{I}^{+}$(the indicator of the contractual wage exceeding the wage ceiling of the highest wage scale) is on average higher in the private sector. Table C1 shows that in general, indicator $\mathrm{I}^{+}$is approximately zero in the public sector. ${ }^{9}$ Since wages above the highest wage scale ceiling are very rare in the public sector, we leave out its results regarding $\mathrm{I}^{+}$in the subsequent tables.

The calculations of the indicators of Table 6 are based on wage regressions for contractual wages. The regressions are implemented for each CLA-sector separately to calculate sector-specific variances (see Section 3). Appendix C2 presents the pooled results for the private and public sectors and for four separate CLA-sectors.

Similar regressions, but for real gross hourly wages (instead of contractual wages), are presented in the Appendix, Table C4, in columns (1) and (3). The lower panel of Table C4 shows the cumulative effects of potential experience and tenure on the log real hourly gross wages. The estimation results confirm the results of Zwick (2012) and Deelen (2012), who found that wages continue increasing with experience and tenure at older ages. Wages do indeed continue increasing with experience, although slightly less so than reported in Deelen (2012), which was based on administrative data for the time period 1999-2005.

\section{Analysis of the wage cushion}

Descriptive statistics show that wage cushions exist in the Dutch private sector, just like in Portugal (Cardoso and Portugal, 2005) and Germany (Jung and Schnabel, 2011). The central

\footnotetext{
${ }^{9}$ The secondary education sector is an exception, caused by the fact that we included wage ceiling for teachers in the dataset, while we are unable to distinguish teachers from governors. The CLA for secondary education contains multiple wage scale tables for various occupations within the sector.
} 
research question in this study is whether these wage cushions are more important at older ages and contribute to the fact that wages continue increasing with experience at older ages. We first investigate whether older workers are more likely to be at a wage ceiling of a wage scale, using indicator $\mathrm{I}^{\overline{ }}$, or receive a wage above the ceiling of the highest wage scale, using indicator $\mathrm{I}^{+}$, for the private and public sector separately.

Table 7 shows the results of regressions explaining the indicators. In the private sector, the indicator of being at a wage scale ceiling increases slightly with age, whereas in the public sector this indicator increases strongly with age and continues increasing at higher ages. This is in line with the fact that the wage scale system is more extended in the public sector. The effect of tenure is clearly positive in the public sector, while in the private sector, the effect of tenure is more modest. The indicator for a wage above the highest wage ceiling increases strongly with age in the private sector.

\section{$<$ INSERT TABLE 7 ABOUT HERE $>$}

Do workers whose wages are equal to the wage scale ceiling receive more in additional wages, as a means to enhance their motivation and productivity? If so, it could help to explain the fact that wage profiles continue increasing over age despite the fact that sooner or later, most workers end up at a wage scale ceiling. Does the position of wages visà-vis the CLA-wage scales explain the share of additional wages (incidental wages plus extra wages) in total wages (contractual wages plus additional wages)? Regression results in the first row of Table 8 show a negative effect of the indicator of a wage at a wage scale ceiling on the additional wage share, in both the private and public sectors. Hence, workers receiving a wage at a wage scale ceiling receive relatively less in additional wages than workers who have not yet reached a ceiling. Apparently, additional wages are not used as a means to motivate workers who find themselves at the ceiling of their wage scale.

For workers receiving a contractual wage exceeding the highest wage scale ceiling, the picture is different. In the private sector, wages exceeding the highest wage ceiling go hand in hand with extra additional wages, as the effect of the indicator $\mathrm{I}^{+}$is significantly positive.

To conclude, for the private sector, the finding that workers with contractual wages exceeding the highest wage ceiling receive more in additional wages provides an explanation for a paradox: wage profiles are increasing over time, while workers reach the end of their 
wage scale sooner or later. We find, however, no indication that additional wages are used to motivate workers who have a wage equal to the maximum of their wage scale.

\section{$<$ INSERT TABLE 8 ABOUT HERE $>$}

Table 9 analyses the effect of the position of wages relative to the wage scales on the growth in contractual wages and additional wages. A wage equal to a wage scale ceiling implies relatively low contractual wage growth, by definition (see equation (3)). The growth in additional wages is lower for workers who have not yet reached the ceiling. Workers earning wages that exceed the highest wage scale ceiling experience a relatively high contractual wage growth. Beyond the boundaries of the CLA-scale system, not only the level but also the growth of contractual wages is higher. The growth of their additional wages is lower, apparently due to the fact that there is less need to use additional wages if contractual wages can be set freely.

$<$ INSERT TABLE 9 ABOUT HERE $>$

\section{Sensitivity analysis}

Table 10 repeats the analysis of Table 9 for two different sets of parameter values used in the calculation of the indicators $\mathrm{I}^{=}$and $\mathrm{I}^{+}$. The indicators change, as do the estimated coefficients, but the overall picture does not change: workers earning wages that exceed the highest wage scale ceiling experience relatively high contractual wage growth.

\section{$<$ INSERT TABLE 10 ABOUT HERE $>$}

What is the effect of wages exceeding the highest wage scale ceiling on the age-wage profile? In the Appendix, Table C4, columns (2) and (5) present wage regressions in which jobs exceeding the highest wage scale ceiling in any year are removed from the dataset in all years. The lower panel of Table C4 shows the cumulative effects of potential experience. Comparing column (2) with column (1), which refers to the full sample, shows that excluding wages exceeding the highest wage scale ceiling clearly reduces the steepness of the wage profile over potential experience. In other words, the group of workers that is paid above the highest CLA-wage ceiling pulls up the age-wage profile. 
Column (3) of Table C4 explores how much self-selection out of work affects the wage profile. The specification includes an attrition dummy measured at time $t+1$, which is also interacted with tenure. The results indicate that the effects of self-selection out of work on the age-wage profile are small; the cumulative effects in the lower panel of the table are grosso modo equal to the effects in column (1). In other words, we find no evidence that selfselection at time $t+1$ is an important explanatory variable in the increasing wage profile over potential experience.

\section{Conclusions}

This study investigates the anatomy of older workers' wages in order to explain the fact that in the Netherlands, wage profiles continue increasing at older ages, despite the fact that most workers end up at a wage scale ceiling sooner or later. The central research question is whether the wage cushion, defined as the difference between actual wages and (maximum) contractual wages as stipulated in collective labour agreements, contributes to the fact that wages continue increasing at older ages. This wage cushion consists of two parts: the first comprises additional wages paid above the contractual wage, and the second consists of the degree to which contractual wages exceed the highest wage scale ceiling, as stipulated in the collective labour agreement.

In the public sector, we find no evidence of a wage cushion leading to wages that continue to increase at older ages. Wage scale ceilings stipulated in collective agreements turn out to be guiding for older workers' wages, whereby the public wage scale system also includes all types of managerial jobs. Workers earning a contractual wage equal to a wage scale ceiling are not compensated with higher additional wages. Moreover, workers receiving a wage at a wage scale ceiling receive even less in additional wages than workers who have not yet reached a wage ceiling. Apparently, additional wages are not used to motivate workers who find themselves at the ceiling of their wage scales.

In the private sector, we do find evidence of a wage cushion leading to wages that continue to increase at older ages. In contrast to the public sector, the wage scale systems in the private sector do not seem to include all types of higher and better paid (managerial) jobs. So wage scale ceilings are not restrictive, as many workers receive a contractual wage exceeding the highest wage scale ceiling. The likelihood of earning such a contractual wage increases with age. Furthermore, workers earning such a contractual wage receive more in additional wages and experience higher contractual wage growth. The growth of their additional wages is, however, low compared to other workers, possibly due to the fact that 
there is less of a need to use additional wages if contractual wages can be set freely. As a result, in the private sector, the wage cushion enhances wage differentiation, and wages higher than the highest wage scale ceiling contribute to the steepness of the age-wage profile. The result leads to the natural question on why the private sector has wage scales with wage ceilings, but we consider this question beyond the scope of the paper and a possible topic for future research on labour market institutions.

In order to draw policy conclusions from our finding that a wage cushion exists in the Dutch private sector, one should know more about the reasons behind it. The fact that wages continue increasing at older ages may be related to firm-specific human capital. Since empirical evidence suggests that productivity at best remains stable at older ages (BörschSupan and Weiss, 2008 and Van Ours and Stoeldraijer, 2011), firm-specific human capital that continues increasing at older ages is not a likely explanation. However, firm investments in firm-specific human capital may go hand in hand with deferred compensation schemes in order to tie employees to their firms. In these cases, wages that continue increasing at older ages may be the result of optimal firm behaviour. Wages that continue increasing at older ages may, however, also be the result of the strong bargaining positions of older workers (Euwals et al., 2009). This may lead to a wage-productivity gap at older ages, negatively affecting job mobility by older workers.

Although we cannot tell what exactly causes wages to continue increasing at older ages, our empirical evidence at least suggests that collective wage bargaining and the collective wage scale systems cannot be a major cause. Wages that continue increasing at older ages in the private sector are the result of a wage cushion-especially that portion of wages that is on top of the collectively-agreed (maximum) wages. Our results indicate that wage differentiation is greater than that suggested by the uniform wage-setting system that prevails in the Netherlands, due to the fact that collective labour agreements usually extend to all workers in a sector of industry. So, at least for the wages of older workers, this may serve as a counterargument to the plea for more decentralized wage-setting institutions. Wage cushions seem to allow for wage differentiation between and within age groups, but it remains unsettled to what degree this wage differentiation allows for heterogeneity across sectors of industry and/or firms. Future research on linked employer-employee data should therefore address to which extent heterogeneity of wages and total wage costs reflects differences in productivity across sectors of industry and firms. 
Figure 1 Histograms of contractual wages for the basic metal industry and the state public administration (wage range 2000 - 2500 Euros, bin width 10 Euros)
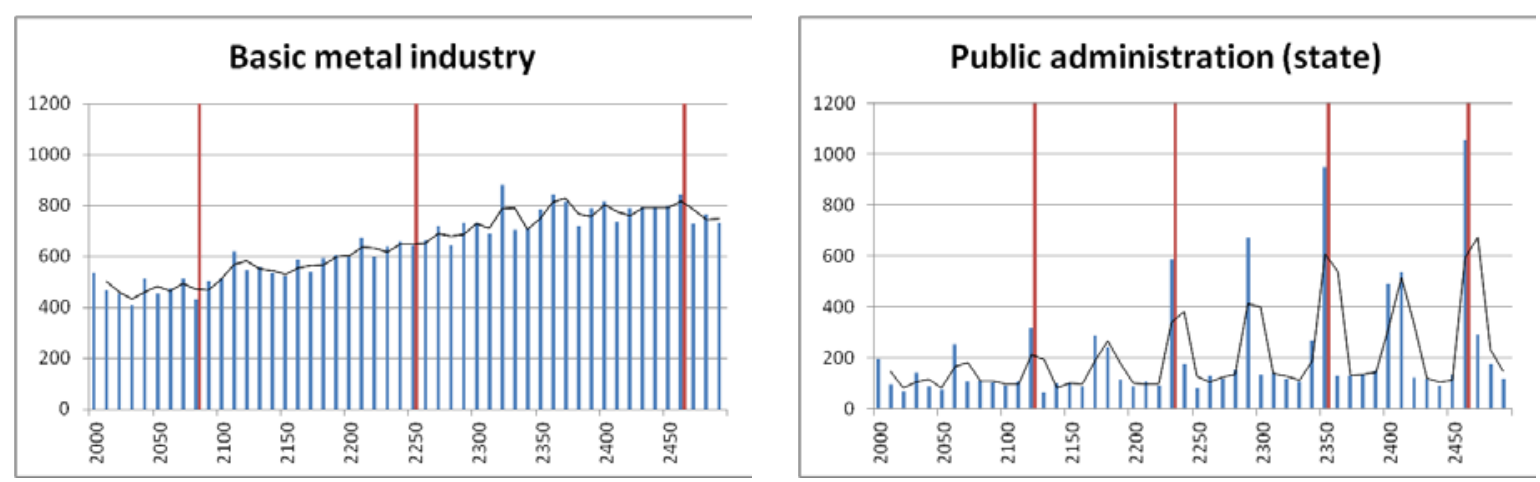

Note: vertical lines depict the ceilings of CLA-wage scales.

Table 1 Wage system of the transportation sector, gross monthly wages, 2006

\begin{tabular}{lrrrrrrrr}
\hline Wage scale & $\mathbf{1}$ & $\mathbf{2}$ & $\mathbf{3}$ & $\mathbf{4}$ & $\mathbf{5}$ & $\mathbf{6}$ & $\mathbf{7}$ & $\mathbf{8}$ \\
\hline Floor & 1432 & 1503 & 1563 & 1629 & 1711 & 1793 & 1876 & 1958 \\
Ceiling & 1710 & 1800 & 1878 & 2000 & 2181 & 2371 & 2606 & 2855 \\
Spinal points & 5 & 5 & 5 & 5 & 6 & 7 & 8 & 9 \\
\hline
\end{tabular}


Table 2 Wage system of 22 large sectors of industry, gross monthly wages, 2006

\begin{tabular}{|c|c|c|c|c|c|c|c|c|}
\hline & & & Lowest & & & lighest & & \\
\hline & sbi08 & \#sc. & floor & ceiling & \#sp.p. & floor & ceiling & \#sp.p. \\
\hline \multicolumn{9}{|l|}{ Private sector } \\
\hline Basic metal industry & 240 & 11 & 1472 & 1485 & 1 & 2166 & 2855 & 10 \\
\hline Metal products industry & 250 & 10 & 1265 & 1537 & 3 & 1738 & 3079 & 14 \\
\hline Coachworks industry & 292 & 10 & 1265 & 1537 & 3 & 1738 & 3079 & 14 \\
\hline Construction installation activities & 432 & 10 & 1265 & 1537 & 3 & 1738 & 3079 & 14 \\
\hline Repair of (motor) vehicles & 452 & 10 & 1265 & 1537 & 3 & 1738 & 3079 & 14 \\
\hline Retail sale (large stores) & 472 & 9 & 1523 & 1523 & 0 & 3160 & 3504 & Flex \\
\hline Retail sale (small stores) & 472 & 9 & 1523 & 1523 & 0 & 3160 & 3504 & Flex \\
\hline Clothing and footwear & 477 & 5 & 1285 & 1285 & 0 & 1671 & 1972 & 6 \\
\hline Transport & 494 & 8 & 1432 & 1710 & 5 & 1958 & 2855 & 9 \\
\hline Hotel and catering & 551 & 11 & 1339 & 1559 & Flex & 2844 & 3584 & Flex \\
\hline Temporary employment agencies $^{1}$ & 782 & 9 & 1317 & 1666 & Flex & 1941 & 3290 & Flex \\
\hline Temporary employment agencies & 782 & 9 & 1317 & 1666 & Flex & 1941 & 3290 & Flex \\
\hline Cleaning & 812 & 7 & 1250 & 1250 & 0 & 1698 & 1764 & 12 \\
\hline \multicolumn{9}{|l|}{ Public sector (including health care) } \\
\hline Social unemployment relief & 329 & 12 & 1252 & 1297 & 2 & 2461 & 3979 & 11 \\
\hline Public adm.(municipality, revised) ${ }^{1}$ & 841 & 20 & 1283 & 1646 & 11 & 5783 & 8220 & 11 \\
\hline Public adm.(municipality) & 841 & 19 & 1283 & 1540 & 5 & 6164 & 8220 & 9 \\
\hline Public administration (region) & 841 & 18 & 1263 & 1598 & Flex & 5818 & 8311 & Flex \\
\hline Public administration (state) & 841 & 18 & 1287 & 1618 & 10 & 6044 & 7934 & 10 \\
\hline Police & 842 & 18 & 1173 & 1751 & 10 & 5470 & 7598 & 11 \\
\hline Secondary education & 853 & 4 & 2242 & 3427 & 17 & 2912 & 4933 & 17 \\
\hline Nursing homes for disabled & 872 & 16 & 1266 & 1543 & 7 & 5200 & 7350 & 14 \\
\hline Social work activities & 889 & 15 & 1342 & 1985 & 15 & 3454 & 7885 & 19 \\
\hline
\end{tabular}

Note: the sectors of industry are chosen on the basis of their large size and the fact that all workers in these industries are covered by the same collective agreement. The code sbi08 refers to standard business classification codes in 2008, \#sc. refers to the number of wage scales, and the floor and ceiling are the lowest and highest wages, respectively, according to the wage scale.

1) Two separate collective labour agreements for temporary work agencies are taken into account. Due to a reform, there are two different wage scale systems for municipalities' public administrations. The revised system holds for employees who started their jobs in 1996 or later. 
Table 3 Descriptive statistics for dataset of all male employees and sample of collective labour agreements, 2008

\begin{tabular}{|c|c|c|c|c|c|c|}
\hline & \multicolumn{3}{|l|}{ all men ${ }^{1}$} & \multicolumn{3}{|c|}{ CLA-sample ${ }^{1}$} \\
\hline & mean & p50 & sd & mean & p50 & sd \\
\hline age & 42,3 & 42,0 & 10,8 & 42,4 & 43,0 & 11,0 \\
\hline tenure & 8,5 & 5,6 & 9,0 & 8,9 & 5,8 & 9,5 \\
\hline potential experience ${ }^{2}$ & 25,1 & 25,0 & 11,6 & 25,6 & 26,0 & 11,5 \\
\hline dummy firm size $10-18$ employees & 0,08 & & 0,27 & 0,07 & & 0,26 \\
\hline dummy firm size 20-49 employees & 0,12 & & 0,33 & 0,12 & & 0,32 \\
\hline dummy firm size 50-99 employees & 0,09 & & 0,28 & 0,09 & & 0,29 \\
\hline dummy firm size 100-199 employees & 0,09 & & 0,28 & 0,09 & & 0,29 \\
\hline dummy firm size 200-499 employees & 0,11 & & 0,32 & 0,12 & & 0,33 \\
\hline dummy firm size $>500$ employees & 0,39 & & 0,49 & 0,44 & & 0,50 \\
\hline dummy reg. contract (=no TWA/on-call) & 0,95 & & 0,21 & 0,89 & & 0,31 \\
\hline dummy fulltime contract & 0,83 & & 0,38 & 0,80 & & 0,40 \\
\hline dummy low educational level $\left.\right|^{3}$ & 0,04 & & 0,20 & 0,05 & & 0,22 \\
\hline dummy intermediate educational level ${ }^{3}$ & 0,12 & & 0,33 & 0,12 & & 0,33 \\
\hline dummy high educational level ${ }^{3}$ & 0,16 & & 0,36 & 0,10 & & 0,31 \\
\hline yearly contractual wage (in Euros) & 35.026 & 31.239 & 23.383 & 29.256 & 27.505 & 15.943 \\
\hline yearly incidental wage (in Euros) & 2.328 & 273 & 15.996 & 1.205 & 241 & 6.404 \\
\hline yearly extra salary (in Euros) & 875 & 0 & 2.680 & 812 & 0 & 1.867 \\
\hline contractual wage per month (in Euros) ${ }^{4}$ & 3.129 & 2.750 & 1.889 & 2.635 & 2.429 & 1.276 \\
\hline gross wage per month (in Euros) ${ }^{4}$ & 3.030 & 2.691 & 2.658 & 2.612 & 2.457 & 1.331 \\
\hline \multicolumn{7}{|c|}{$\begin{array}{l}{ }^{1} \text { statistics for 'all men' are based on 3,3 million observations, while statistics for 'CLA-sample' are } \\
\text { based on 1,0 million observations for male workers. }\end{array}$} \\
\hline \multirow{2}{*}{\multicolumn{7}{|c|}{$\begin{array}{l}2 \text { potential experience is defined as age minus years of education, determined using the highest level } \\
\text { of education attained, minus four years that represent the period before entering primary school. } \\
\text { Time in the educational system cannot be less than } 12 \text { years because education is compulsory until } \\
\text { age } 16 .\end{array}$}} \\
\hline & & & & & & \\
\hline \multicolumn{7}{|c|}{${ }^{3}$ Level of education is available for approximately one third of the observations in our dataset. } \\
\hline \multicolumn{7}{|c|}{$\begin{array}{l}{ }^{4} \text { Wages are observed in the month October as we consider this as a relatively representative month, } \\
\text { we do not consider yearly wages as the wage level of many workers changes during the year. }\end{array}$} \\
\hline
\end{tabular}


Table 4 Average gross contractual and additional wages per age group, by collective labour agreement, 2008

\begin{tabular}{|c|c|c|c|c|c|c|c|c|}
\hline & \multicolumn{4}{|c|}{ average contractual wage } & \multicolumn{4}{|c|}{ average additional wage ${ }^{1}$} \\
\hline & $23-34$ & $35-44$ & $45-54$ & $55-64$ & $23-34$ & $35-44$ & $45-54$ & $55-64$ \\
\hline \multicolumn{9}{|l|}{ Private sector } \\
\hline Basic metal industry & 27954 & 35896 & 37938 & 37763 & 1973 & 3084 & 3601 & 3527 \\
\hline Metal products industry & 25226 & 32383 & 34518 & 33096 & 1326 & 1939 & 2208 & 2389 \\
\hline Coachworks industry & 23948 & 30544 & 31896 & 29347 & 776 & 1013 & 1107 & 1082 \\
\hline Construction installation activ. & 25866 & 33758 & 36468 & 35186 & 1286 & 2209 & 2626 & 2537 \\
\hline Repair of (motor) vehicles & 23900 & 32016 & 33432 & 29322 & 1163 & 1802 & 1784 & 1489 \\
\hline Retail sale (large stores) & 20506 & 29904 & 32234 & 32957 & 897 & 1364 & 1592 & 2103 \\
\hline Retail sale (small stores) & 19116 & 29615 & 33449 & 28772 & 382 & 825 & 1097 & 1537 \\
\hline Clothing and footwear & 18985 & 29580 & 33043 & 29072 & 671 & 1573 & 1761 & 1039 \\
\hline Transport & 23260 & 26837 & 27152 & 25398 & 995 & 1288 & 1273 & 1153 \\
\hline Hotel and catering & 16646 & 22410 & 22863 & 19323 & 265 & 743 & 762 & 560 \\
\hline Temp. employment agencies & 12044 & 15734 & 16960 & 17196 & 414 & 528 & 486 & 514 \\
\hline Temp. employment agencies & 10885 & 13878 & 14644 & 14351 & 283 & 366 & 370 & 371 \\
\hline Cleaning & 16847 & 20901 & 21361 & 19228 & 349 & 569 & 644 & 531 \\
\hline \multicolumn{9}{|l|}{ Public sector (incl. health care) } \\
\hline Social unemployment relief & 16670 & 18553 & 19587 & 19678 & 615 & 688 & 739 & 744 \\
\hline Public administration (munic.) & 29020 & 35754 & 39318 & 38517 & 2538 & 3168 & 3562 & 3292 \\
\hline Public administration (munic.) & 29421 & 35671 & 39618 & 39137 & 2844 & 3231 & 3635 & 3262 \\
\hline Public administration (region) & 32106 & 39284 & 43576 & 43110 & 3627 & 4563 & 5028 & 4956 \\
\hline Public administration (state) & 30225 & 41470 & 45559 & 47687 & 3200 & 3755 & 3555 & 3031 \\
\hline Police & 28168 & 37113 & 42980 & 43909 & 4880 & 5381 & 5641 & 5437 \\
\hline Secondary education & 25312 & 32481 & 39692 & 40923 & 1909 & 2505 & 3154 & 3250 \\
\hline Nursing homes for disabled & 21447 & 27131 & 31956 & 32682 & 1111 & 1473 & 1759 & 1768 \\
\hline Social work activities & 22217 & 28679 & 32345 & 32260 & 1142 & 1492 & 1685 & 1727 \\
\hline
\end{tabular}

${ }^{1}$ Additional wages refers to the sum of incidental wages (performance-related, not part of the contract) and extra wages (a regular extra wage component, e.g., a thirteenth month of salary). 
Table 5 Incidence of additional wage and of contractual wages exceeding collectively agreed wage ceiling, by CLA and age-groups, 2008

\begin{tabular}{|c|c|c|c|c|c|c|c|c|}
\hline \multirow[b]{2}{*}{ CLA } & \multicolumn{4}{|c|}{ incidence additional wage } & \multicolumn{4}{|c|}{$\begin{array}{l}\text { incidence wage exceeding } \\
\text { ceiling highest CLA-scale }\end{array}$} \\
\hline & $23-34$ & $35-44$ & $45-54$ & $55-64$ & $23-34$ & $35-44$ & $45-54$ & $55-64$ \\
\hline \multicolumn{9}{|l|}{ Private sector } \\
\hline Basic metal industry & 0,92 & 0,89 & 0,90 & 0,88 & 0,03 & 0,01 & 0,00 & 0,01 \\
\hline Metal products industry & 0,95 & 0,94 & 0,94 & 0,92 & 0,06 & 0,21 & 0,25 & 0,25 \\
\hline Coachworks industry & 0,94 & 0,93 & 0,94 & 0,90 & 0,04 & 0,15 & 0,16 & 0,18 \\
\hline Construction install. activ. & 0,94 & 0,94 & 0,94 & 0,92 & 0,06 & 0,25 & 0,32 & 0,32 \\
\hline Repair of (motor) vehicles & 0,93 & 0,92 & 0,92 & 0,88 & 0,05 & 0,19 & 0,22 & 0,20 \\
\hline Retail sale (large stores) & 0,77 & 0,73 & 0,73 & 0,74 & 0,03 & 0,10 & 0,14 & 0,14 \\
\hline Retail sale (small stores) & 0,37 & 0,40 & 0,38 & 0,39 & 0,02 & 0,10 & 0,17 & 0,15 \\
\hline Clothing and footwear & 0,60 & 0,56 & 0,53 & 0,51 & 0,32 & 0,68 & 0,72 & 0,73 \\
\hline Transport & 0,86 & 0,84 & 0,83 & 0,80 & 0,10 & 0,17 & 0,16 & 0,14 \\
\hline Hotel and catering & 0,32 & 0,35 & 0,34 & 0,33 & 0,01 & 0,05 & 0,06 & 0,06 \\
\hline Temp. empl. agencies & 0,67 & 0,68 & 0,63 & 0,63 & 0,02 & 0,04 & 0,05 & 0,07 \\
\hline Temp. empl. agencies & 0,71 & 0,72 & 0,72 & 0,70 & 0,02 & 0,03 & 0,04 & 0,08 \\
\hline Cleaning & 0,48 & 0,51 & 0,52 & 0,48 & 0,30 & 0,42 & 0,41 & 0,41 \\
\hline \multicolumn{9}{|c|}{ Public sector (incl. health care) } \\
\hline Social unempl. relief & 1,00 & 1,00 & 1,00 & 1,00 & 0,00 & 0,00 & 0,00 & 0,00 \\
\hline Public adm. (munic.) & 0,99 & 1,00 & 0,99 & 0,98 & 0,00 & 0,00 & 0,00 & 0,01 \\
\hline Public adm. (munic.) & 0,96 & 0,99 & 1,00 & 1,00 & 0,00 & 0,00 & 0,00 & 0,00 \\
\hline Public adm. (region) & 1,00 & 1,00 & 1,00 & 1,00 & 0,00 & 0,00 & 0,00 & 0,01 \\
\hline Public adm. (state) & 1,00 & 1,00 & 1,00 & 0,99 & 0,00 & 0,00 & 0,01 & 0,01 \\
\hline Police & 1,00 & 1,00 & 1,00 & 1,00 & 0,00 & 0,00 & 0,00 & 0,01 \\
\hline Secondary education & 1,00 & 1,00 & 1,00 & 1,00 & 0,00 & 0,00 & 0,00 & 0,02 \\
\hline Nursing homes disabled & 0,99 & 0,99 & 0,99 & 0,98 & 0,00 & 0,00 & 0,01 & 0,02 \\
\hline Social work activities & 0,98 & 0,98 & 0,98 & 0,98 & 0,00 & 0,00 & 0,00 & 0,00 \\
\hline
\end{tabular}


Table 6 Descriptive statistics Indicators ${ }^{1}$

\begin{tabular}{|c|c|c|c|c|c|c|c|c|}
\hline & \multicolumn{4}{|c|}{ I1 } & \multicolumn{4}{|l|}{12} \\
\hline & mean & sd & $\min$ & $\max$ & mean & sd & $\min$ & $\max$ \\
\hline private sector & 0,81 & 0,36 & 0,00 & 1,00 & 0,38 & 0,32 & 0,00 & 0,92 \\
\hline \multirow[t]{3}{*}{ public sector } & 0,90 & 0,23 & 0,00 & 1,00 & 0,50 & 0,35 & 0,00 & 0,99 \\
\hline & \multicolumn{4}{|c|}{ indicator wage equal to scale ceiling $\left(\mathrm{I}^{-}\right)$} & \multicolumn{4}{|c|}{ indicator wage above highest ceiling $\left(\mathrm{I}^{+}\right)$} \\
\hline & mean & sd & $\min$ & $\max$ & mean & sd & $\min$ & $\max$ \\
\hline private sector & 0,31 & 0,32 & 0,00 & 0,92 & 0,15 & 0,34 & 0,00 & 1,00 \\
\hline public sector & 0,44 & 0,35 & 0,00 & 0,96 & 0,02 & 0,09 & 0,00 & 1,00 \\
\hline
\end{tabular}

1) Indicator I1 reflects the proximity of the individual contractual wage to the wage ceiling of a wage scale (equation (2) in Section 3), indicator 12 reflects the proximity of contractual wage growth to collectively agreed wage growth (equation (3) in Section 3), indicator $\mathrm{I}^{=}$is the indicator of the contractual wage being at the wage ceiling of a wage scale and combines the information of $I 1$ and 12 (Appendix B). Indicator $\mathrm{I}^{+}$is the indicator of the contractual wage exceeding the wage ceiling of the highest wage scale (Appendix B). Descriptive statistics for the underlying CLA-sectors are presented in the Appendix, Table $\mathrm{C} 1$.

Table 7 The effects of age and tenure on the indicators describing the position of contractual wages vis-à-vis the CLA-wage scales ${ }^{1}$

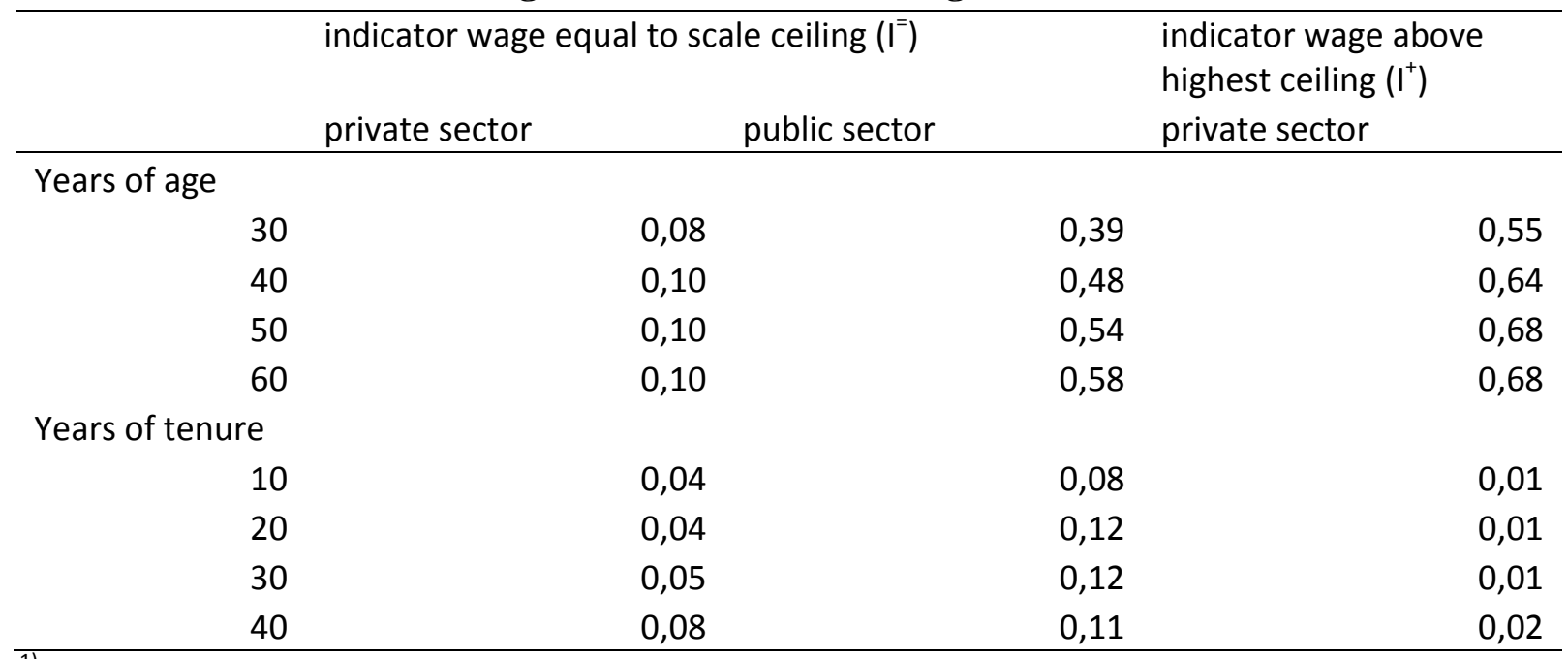

${ }^{1)}$ Indicator I= is the indicator of the contractual wage being at the wage ceiling of a wage scale and combines the information of II and II (Indicator II reflects the proximity of the individual contractual wage to the wage ceiling of a wage scale, indicator 12 reflects the proximity of contractual wage growth to collectively agreed wage growth). Indicator $\mathrm{I}+\mathrm{is}$ the indicator of the contractual wage exceeding the wage ceiling of the highest wage scale.

The effects of age and tenure are obtained from random effects regressions containing age and age ${ }^{2}$ and tenure, tenure ${ }^{2}$, tenure ${ }^{3}$ and tenure ${ }^{4}$. Included as control variables are two dummy variables for the level of education, four year variables, a dummy for fulltime contracts, five dummies representing the size class of the firm as well as dummies for the CLA sectors of industry. The underlying regression results for $\mathrm{I}^{-}$and $\mathrm{I}^{+}$can be found in the Appendix (Table C3). The results of $\mathrm{I}^{+}$in the public sector are left out since according to Table 5 the incidence of wages above the highest wage scale is very low. 
Table 8 Does additional wage depend on the indicators?

\begin{tabular}{lll}
\hline & private sector & public sector \\
\hline indicator wage equal to scale ceiling $\left(I^{*}\right)$ & $-0.0038^{* * *}$ & $-0.0042^{* * *}$ \\
& $(0.000153)$ & $(0.000142)$ \\
indicator wage above highest ceiling $\left(I^{+}\right)$ & $0.0073^{* * *}$ & \\
& $(0.000337)$ & \\
& & \\
Observations & 1524927 & 1336327 \\
Groups & 585358 & 438227 \\
R2 within & 0.0002 & 0.1457 \\
R2 overall & 0.0738 & 0.1371 \\
R2 between & 0.0912 & 0.1368 \\
\hline
\end{tabular}

Standard errors in parentheses; ${ }^{*} p<0.05, * * p<0.01,{ }^{* * *} p<0.001$

Note: Based on random effects regressions. The dependent variable is the share of additional wages in total wages, where total wages are the sum of contractual wages and additional wages, while additional wages are the sum of incidental wages (performance-related, not part of the contract) and extra wages (a regular extra wage component, e.g., a thirteenth month of salary).

Explanatory variables of interest: Indicator $\mathrm{I}=$ is the indicator of the contractual wage being equal to the wage ceiling of a wage scale. Indicator $\mathrm{I}+$ is the indicator of the contractual wage exceeding the wage ceiling of the highest wage scale.

Control variables: tenure is instrumented with the deviation between tenure and the individual job average of tenure, and potential experience is instrumented likewise. Furthermore, we have taken into account all four year variables, two dummy variables for the level of education, a dummy for fulltime contracts, five dummies representing the size class of the firm as well as 22 dummies for the CLA sectors of industry and a constant. The results of $I^{+}$in the public sector are left out since according to Table 5 the incidence of wages above the highest wage scale is very low. 


\begin{tabular}{|c|c|c|c|c|}
\hline & \multicolumn{2}{|c|}{ growth in contractual wage } & \multicolumn{2}{|c|}{ growth in additional wage } \\
\hline & private sector & public sector & private sector & public sector \\
\hline \multicolumn{5}{|c|}{ indicator wage equal to } \\
\hline \multirow[t]{2}{*}{ scale ceiling $\left(I^{\mp}\right)$} & $-0.0183 * * *$ & $-0.0544 * * *$ & $-1.465 * * *$ & $-0.302 * * *$ \\
\hline & $(0.00355)$ & $(0.00255)$ & $(0.383)$ & $(0.0528)$ \\
\hline \multicolumn{5}{|c|}{ indicator wage above } \\
\hline \multirow[t]{2}{*}{ highest ceiling $\left(\mathrm{I}^{+}\right)$} & $0.390 * * *$ & & $-1.914 * *$ & \\
\hline & $(0.00823)$ & & $(0.605)$ & \\
\hline Observations & 1524927 & 1336327 & 1267886 & 1305273 \\
\hline Groups & 585358 & 438227 & 512370 & 428324 \\
\hline R2 within & 0.0163 & 0.0052 & 0.0018 & 0.0012 \\
\hline R2 between & 0.0012 & 0.0037 & 0.0010 & 0.0006 \\
\hline R2 overall & 0.0003 & 0.0039 & 0.0008 & 0.0006 \\
\hline
\end{tabular}

Standard errors in parentheses; ${ }^{*} p<0.05, * * p<0.01, * * * p<0.001$

Note: Based on random effects regressions. The dependent variable is the growth in contractual wages or additional wages. Additional wages refer to the sum of annual incidental wages (performance-related, not part of the contract) and extra wages (regular, extra wage component; e.g., a thirteenth month of salary). Growth in contractual wages is based on the wage for October and is rescaled to a full-time wage in cases of part-time contracts.

Explanatory variables of interest: Indicator $I=$ is the indicator of the contractual wage being equal to the wage ceiling of a wage scale. Indicator $\mathrm{I}+$ is the indicator of the contractual wage exceeding the wage ceiling of the highest wage scale.

Control variables: tenure is instrumented with the deviation between tenure, and the individual job average of tenure and potential experience is instrumented likewise. Furthermore, we have taken into account all four-year variables, two dummy variables for the level of education, a dummy for full-time contracts, five dummies representing the size class of the firm, as well as $\mathbf{2 2}$ dummies for the CLA sectors of industry and a constant. The results of $\mathrm{I}^{+}$in the public sector are left out since, according to Table 5, the incidence of wages above the highest wage scale is very low. 
Table 10 Does contractual wage growth depend on the indicators? Sensitivity analysis with alternative indicators

\begin{tabular}{|c|c|c|c|c|c|c|}
\hline & \multicolumn{3}{|c|}{ private sector CLA's } & \multicolumn{3}{|c|}{ public sector CLA's } \\
\hline & base case & alternative 1 & alternative 2 & base case & alternative 1 & alternative 2 \\
\hline indicator wage & & & & & $-0.0882 * * *$ & $-0.0131 * * *$ \\
\hline \multicolumn{7}{|l|}{ equal to scale } \\
\hline \multirow[t]{2}{*}{ ceiling $\left(I^{=}\right)$} & $-0.0183 * * *$ & $-0.0263 * * *$ & $-0.0884 * * *$ & $-0.0544 * * *$ & & \\
\hline & $(0.00355)$ & $(0.00703)$ & $(0.0226)$ & $(0.00255)$ & $(0.00432)$ & $(0.00586)$ \\
\hline \multicolumn{7}{|l|}{ indicator wage } \\
\hline \multicolumn{7}{|l|}{ above highest } \\
\hline \multirow[t]{2}{*}{ ceiling $\left(\mathrm{I}^{+}\right)$} & $0.390 * * *$ & $0.357^{* * *}$ & $0.468 * * *$ & & & \\
\hline & $(0.00823)$ & $(0.00785)$ & $(0.00987)$ & & & \\
\hline Observations & 1524927 & 1524927 & 1524927 & 1336327 & 1336327 & 1336327 \\
\hline Groups & 585358 & 585358 & 585358 & 438227 & 438227 & 438227 \\
\hline R2 within & 0.0163 & 0.0154 & 0.0203 & 0.0052 & 0.0057 & 0.0064 \\
\hline R2 overall & 0.0012 & 0.0012 & 0.0013 & 0.0037 & 0.0036 & 0.0042 \\
\hline $\mathrm{R} 2$ between & 0.0003 & 0.0003 & 0.0004 & 0.0004 & 0.0036 & 0.0044 \\
\hline
\end{tabular}

Standard errors in parentheses; ${ }^{*} p<0.05,{ }^{* *} p<0.01,{ }^{* * *} p<0.001$

Note:

Sensitivity analysis regarding different sets of parameter values in the calculation of the indicators.

Base case: $\quad \delta=1,0 ; \gamma_{1}=0.01 ; \gamma_{2}=0.05$. The mean of $\mathrm{I}^{=}=0.31$ and the of mean $\mathrm{I}^{+}=0.15$

Alternative 1: $\delta=0.5 ; \gamma_{1}=0.01 ; \gamma_{2}=0.05$. The mean of $\mathrm{I}^{=}=0.13$ and the of mean $\mathrm{I}^{+}=0.18$

Alternative 2: $\delta=1,0 ; \gamma_{1}=0.05 ; \gamma_{2}=0.25$. The mean of $\mathrm{I}^{=}=0.25$ and the of mean $\mathrm{I}^{+}=0.19$

For each case we assume $h_{1}=0.10$ and $h_{2}=0.015$.

Note: Based on random effects regressions.

The dependent variable is the growth in contractual wages or additional wages. Additional wages refer to the sum of annual incidental wages (performance-related, not part of the contract) and extra wages (regular, extra wage component; e.g., a thirteenth month of salary). Growth in contractual wages is based on the wage for October and is rescaled to a full-time wage in cases of part-time contracts.

Explanatory variables of interest: Indicator $I=$ is the indicator of the contractual wage being equal to the wage ceiling of a wage scale. Indicator $\mathrm{I}+$ is the indicator of the contractual wage exceeding the wage ceiling of the highest wage scale. Control variables: tenure is instrumented with the deviation between tenure, and the individual job average of tenure and potential experience is instrumented likewise. Furthermore, we have taken into account all four-year variables, two dummy variables for the level of education, a dummy for full-time contracts, five dummies representing the size class of the firm, as well as 22 dummies for the CLA sectors of industry and a constant. The results of $\mathrm{I}^{+}$in the public sector are left out since, according to Table 5, the incidence of wages above the highest wage scale is very low. 


\section{Appendix A: Collection and merging of wage system information}

To investigate the impact of the wage systems on wages, and in particular the impact of wage ceilings on wages of older workers, we collected the wage system information of twenty-two Dutch sectors of industry. The twenty-two sectors are chosen on the basis of their size, in number of workers covered by a collective agreement, to guarantee a large number of observations in the empirical analysis. The wage system information is stipulated in the collective labour agreements. We extract the information from a database of collective labour agreements from the Dutch Ministry of Social Affairs and Employment. We extract information on the code of the collective labour agreement, the SBI 93 and 08 codes, the starting and final dates of the agreement, the hours of a full-time working week, the number of wage scales and, for each wage scale, the wage floor, the wage ceiling and the number of spinal points.

The wage system information is merged with administrative employment and income data for all Dutch citizens. The two data sources are merged on the basis of the collective agreement code. 


\section{Appendix B: Probability of receiving a contractual wage equal to a wage scale ceiling and exceeding the highest wage scale ceiling}

We assume a worker receives a contractual wage $W_{i t}$ equal to the wage ceiling $W_{j}^{\max }$ of wage scale $j$ in cases in which (1) his wage is close to the wage ceiling of the wage scale and (2) his real wage growth is close to zero. To calculate the joint probability of both conditions, one needs to take into account the fact that the error terms are correlated. Section 3 defines the probability of the two events separately; the joint probability is defined as follows:

$I_{i t}^{=}=P\left(\left(\begin{array}{l}W_{i t}-W_{j}^{\max } \\ W_{i t}-W_{i t-1}\end{array}\right)-\left(\begin{array}{c}\delta h_{1} \\ 2 \delta h_{2}\end{array}\right)<\left(\begin{array}{c}\varepsilon_{i t}^{T} \\ \varepsilon_{i t}^{U}\end{array}\right) \leq\left(\begin{array}{l}W_{i t}-W_{j}^{\max } \\ W_{i t}-W_{i t-1}\end{array}\right)+\left(\begin{array}{c}\delta h_{1} \\ 2 \delta h_{2}\end{array}\right)\right)$

with $\left(\begin{array}{c}\varepsilon_{i t}^{T} \\ \varepsilon_{i t}^{U}\end{array}\right)=\left(\begin{array}{c}\varepsilon_{i t}+\varepsilon_{i} \\ \varepsilon_{i t}-\varepsilon_{i t-1}\end{array}\right) \sim N\left(\left(\begin{array}{l}0 \\ 0\end{array}\right),\left(\begin{array}{cc}\left(\gamma_{1} \sigma_{\omega 1}^{2}+\gamma_{2} \sigma_{\omega 2}^{2}\right) & \gamma_{2} \sigma_{\omega 2}^{2} \\ \gamma_{2} \sigma_{\omega 2}^{2} & 2 \gamma_{2} \sigma_{\omega 2}^{2}\end{array}\right)\right)$

$I_{i t}^{+}$is calculated as:

$I_{i t}^{+}=P\left(W_{i t}^{*}>W_{j}^{\text {max }}\right)=P\left(\varepsilon_{i t}^{T} \leq\left(W_{i t}-W_{j}^{\max }\right)-\delta h_{1}\right)$

with $\varepsilon_{i t}^{T}=\varepsilon_{i}+\varepsilon_{i t} \sim N\left(0,\left(\gamma_{1} \sigma_{\omega 1}^{2}+\gamma_{2} \sigma_{\omega 2}^{2}\right)\right)$ 


\section{Appendix C: Additional statistics}

Table C1 Descriptive statistics of the indicators ${ }^{1}$

\begin{tabular}{llllllllll}
\hline & II & & & & \multicolumn{1}{l}{ I2 } & & & \\
CLA & mean & sd & min & max & mean & sd & min & max \\
\hline Private sector & & & & & & & & & \\
Basic metal industry & 0,74 & 0,41 & 0,00 & 1,00 & 0,38 & 0,31 & 0,00 & 0,79 \\
Metal products industry & 0,85 & 0,33 & 0,00 & 1,00 & 0,39 & 0,32 & 0,00 & 0,83 \\
Coachworks industry & 0,89 & 0,29 & 0,00 & 1,00 & 0,45 & 0,37 & 0,00 & 0,92 \\
Construction install. act. & 0,84 & 0,34 & 0,00 & 1,00 & 0,38 & 0,33 & 0,00 & 0,83 \\
Repair of (motor) vehicles & 0,86 & 0,33 & 0,00 & 1,00 & 0,45 & 0,34 & 0,00 & 0,86 \\
Retail sale (large stores) & 0,74 & 0,23 & 0,00 & 0,87 & 0,40 & 0,34 & 0,00 & 0,81 \\
Retail sale (small stores) & 0,91 & 0,23 & 0,00 & 1,00 & 0,61 & 0,37 & 0,00 & 0,92 \\
Clothing and footwear & 0,61 & 0,45 & 0,00 & 1,00 & 0,32 & 0,28 & 0,00 & 0,72 \\
Transport & 0,86 & 0,32 & 0,00 & 1,00 & 0,34 & 0,27 & 0,00 & 0,66 \\
Hotel and catering & 0,87 & 0,29 & 0,00 & 1,00 & 0,38 & 0,33 & 0,00 & 0,83 \\
Temp. employment agencies & 0,66 & 0,43 & 0,00 & 1,00 & 0,31 & 0,29 & 0,00 & 0,71 \\
Temp. employment agencies & 0,65 & 0,35 & 0,00 & 0,90 & 0,31 & 0,28 & 0,00 & 0,70 \\
Cleaning & 0,73 & 0,41 & 0,00 & 1,00 & 0,34 & 0,33 & 0,00 & 0,77 \\
Public sector (incl. health care) & & & & & & & & \\
Social unempl. relief & 0,33 & 0,03 & 0,00 & 0,34 & 0,40 & 0,42 & 0,00 & 0,99 \\
Public administration (munic.) & 0,98 & 0,12 & 0,00 & 1,00 & 0,51 & 0,34 & 0,00 & 0,88 \\
Public administration (munic.) & 0,97 & 0,06 & 0,00 & 1,00 & 0,64 & 0,31 & 0,00 & 0,87 \\
Public administration (region) & 0,97 & 0,10 & 0,00 & 1,00 & 0,63 & 0,37 & 0,00 & 0,96 \\
Public administration (state) & 0,97 & 0,08 & 0,00 & 1,00 & 0,56 & 0,35 & 0,00 & 0,91 \\
Police & 0,94 & 0,16 & 0,00 & 0,99 & 0,31 & 0,16 & 0,00 & 0,48 \\
Secondary education & 0,97 & 0,07 & 0,00 & 1,00 & 0,33 & 0,37 & 0,00 & 0,92 \\
Nursing homes disabled & 0,96 & 0,13 & 0,00 & 1,00 & 0,49 & 0,37 & 0,00 & 0,92 \\
Social work activities & 0,81 & 0,36 & 0,00 & 1,00 & 0,49 & 0,36 & 0,00 & 0,93 \\
\hline & & & & & & & &
\end{tabular}




\begin{tabular}{|c|c|c|c|c|c|c|c|c|}
\hline \multirow[b]{2}{*}{ CLA } & \multicolumn{4}{|l|}{$\mathrm{I}^{=}$} & \multicolumn{4}{|l|}{$\mathrm{I}^{+}$} \\
\hline & mean & sd & $\min$ & $\max$ & mean & sd & $\min$ & $\max$ \\
\hline \multicolumn{9}{|l|}{ Private sector } \\
\hline Basic metal industry & 0,28 & 0,31 & 0,00 & 0,79 & 0,25 & 0,42 & 0,00 & 1,00 \\
\hline Metal products industry & 0,33 & 0,32 & 0,00 & 0,83 & 0,13 & 0,33 & 0,00 & 1,00 \\
\hline Coachworks industry & 0,40 & 0,37 & 0,00 & 0,92 & 0,08 & 0,27 & 0,00 & 1,00 \\
\hline Construction install. act. & 0,32 & 0,33 & 0,00 & 0,82 & 0,14 & 0,34 & 0,00 & 1,00 \\
\hline Repair of (motor) vehicles & 0,38 & 0,35 & 0,00 & 0,85 & 0,11 & 0,31 & 0,00 & 1,00 \\
\hline Retail sale (large stores) & 0,30 & 0,28 & 0,00 & 0,71 & 0,07 & 0,25 & 0,00 & 1,00 \\
\hline Retail sale (small stores) & 0,56 & 0,33 & 0,00 & 0,92 & 0,03 & 0,17 & 0,00 & 1,00 \\
\hline Clothing and footwear & 0,18 & 0,27 & 0,00 & 0,72 & 0,37 & 0,46 & 0,00 & 1,00 \\
\hline Transport & 0,29 & 0,24 & 0,00 & 0,66 & 0,10 & 0,29 & 0,00 & 1,00 \\
\hline Hotel and catering & 0,34 & 0,31 & 0,00 & 0,83 & 0,03 & 0,16 & 0,00 & 1,00 \\
\hline Temp. employment agencies & 0,21 & 0,14 & 0,00 & 0,71 & 0,04 & 0,19 & 0,00 & 1,00 \\
\hline Temp. employment agencies & 0,22 & 0,35 & 0,00 & 0,63 & 0,08 & 0,25 & 0,00 & 1,00 \\
\hline Cleaning & 0,26 & 0,31 & 0,00 & 0,77 & 0,23 & 0,40 & 0,00 & 1,00 \\
\hline \multicolumn{9}{|l|}{ Public sector (incl. health care) } \\
\hline Social unempl. relief & 0,13 & 0,14 & 0,00 & 0,33 & 0,02 & 0,09 & 0,00 & 1,00 \\
\hline Public administration (munic.) & 0,49 & 0,35 & 0,00 & 0,88 & 0,00 & 0,04 & 0,00 & 1,00 \\
\hline Public administration (munic.) & 0,63 & 0,31 & 0,00 & 0,87 & 0,00 & 0,04 & 0,00 & 1,00 \\
\hline Public administration (region) & 0,61 & 0,36 & 0,00 & 0,96 & 0,00 & 0,03 & 0,00 & 1,00 \\
\hline Public administration (state) & 0,55 & 0,35 & 0,00 & 0,91 & 0,00 & 0,06 & 0,00 & 1,00 \\
\hline Police & 0,24 & 0,19 & 0,00 & 0,48 & 0,01 & 0,10 & 0,00 & 1,00 \\
\hline Secondary education & 0,32 & 0,36 & 0,00 & 0,92 & 0,07 & 0,04 & 0,00 & 1,00 \\
\hline Nursing homes disabled & 0,48 & 0,37 & 0,00 & 0,92 & 0,01 & 0,08 & 0,00 & 1,00 \\
\hline Social work activities & 0,41 & 0,37 & 0,00 & 0,92 & 0,00 & 0,03 & 0,00 & 1,00 \\
\hline
\end{tabular}

${ }^{1)}$ Indicator I1 reflects the proximity of the individual contractual wages to the wage ceiling of a wage scale, indicator 12 reflects the proximity of contractual wage growth to collectively-agreed wage growth, indicator $\mathrm{I}{ }$ is the indicator of the contractual wages being at the wage ceiling of a wage scale and combines the information of $\mathrm{I} 1$ and $\mathrm{I} 2$. Indicator $\mathrm{I}^{+}$is the indicator of the contractual wage exceeding the wage ceiling of the highest wage scale.

For the base case we assume the sensitivity parameters $\delta=1, \gamma_{1}=0.01$ and $\gamma_{2}=0.05$. For each CLA-sector we assume $h_{1}=0.10$ and $h_{2}=0.015$. 
Table C2 Regressions for log real hourly contractual wage and resulting wage profiles over tenure and potential experience

\begin{tabular}{|c|c|c|c|c|c|c|}
\hline & $\begin{array}{l}(1) \\
\text { Private } \\
\text { sector CLA's }\end{array}$ & $\begin{array}{l}(2) \\
\text { Public } \\
\text { sector CLA's }\end{array}$ & $\begin{array}{l}\text { (3) } \\
\text { Basic metal } \\
\text { industry }\end{array}$ & $\begin{array}{l}\text { (4) } \\
\text { Transport }\end{array}$ & $\begin{array}{l}\text { (5) } \\
\text { Public adm. } \\
\text { (state) }\end{array}$ & $\begin{array}{l}\text { (6) } \\
\text { Secondary } \\
\text { education }\end{array}$ \\
\hline tenure & $\begin{array}{l}0.00118 * * * \\
(0.000133)\end{array}$ & $\begin{array}{l}0.00588 * * * \\
(0.000176)\end{array}$ & $\begin{array}{l}0.00266 * * * \\
(0.000247)\end{array}$ & $\begin{array}{l}0.00330 * * * \\
(0.000423)\end{array}$ & $\begin{array}{l}0.00524 * * * \\
(0.000260)\end{array}$ & $\begin{array}{l}-0.00000645 \\
(0.000390)\end{array}$ \\
\hline tenure ${ }^{2}$ & $\begin{array}{l}-0.0120 * * * \\
(0.000928)\end{array}$ & $\begin{array}{l}-0.0407 * * * \\
(0.000995)\end{array}$ & $\begin{array}{l}-0.0169 * * * \\
(0.00155)\end{array}$ & $\begin{array}{l}-0.0254^{* * *} \\
(0.00349)\end{array}$ & $\begin{array}{l}-0.0305^{* * *} \\
(0.00142)\end{array}$ & $\begin{array}{l}-0.00303 \\
(0.00281)\end{array}$ \\
\hline tenure ${ }^{3}$ & $\begin{array}{l}0.00266 * * * \\
(0.000186)\end{array}$ & $\begin{array}{l}0.00269 * * * \\
(0.000174)\end{array}$ & $\begin{array}{l}0.00214 * * * \\
(0.000284)\end{array}$ & $\begin{array}{l}0.00483 * * * \\
(0.000860)\end{array}$ & $\begin{array}{l}0.00307^{* * *} \\
(0.000236)\end{array}$ & $\begin{array}{l}-0.00119 \\
(0.000633)\end{array}$ \\
\hline $\begin{array}{l}\text { potential } \\
\text { experience }\end{array}$ & $\begin{array}{l}0.0851 * * * \\
(0.000647)\end{array}$ & $\begin{array}{l}0.0692 * * * \\
(0.000667)\end{array}$ & $\begin{array}{l}0.0942 * * * \\
(0.00120)\end{array}$ & $\begin{array}{l}0.0706 * * * \\
(0.00227)\end{array}$ & $\begin{array}{l}0.0806 * * * \\
(0.00104)\end{array}$ & $\begin{array}{l}0.0418 * * * \\
(0.00140)\end{array}$ \\
\hline $\begin{array}{l}\text { potential } \\
\text { experience }^{2}\end{array}$ & $\begin{array}{l}-0.319 * * * \\
(0.00451)\end{array}$ & $\begin{array}{l}-0.190 * * * \\
(0.00446)\end{array}$ & $\begin{array}{l}-0.320 * * * \\
(0.00820)\end{array}$ & $\begin{array}{l}-0.287^{* * *} \\
(0.0154)\end{array}$ & $\begin{array}{l}-0.261 * * * \\
(0.00678)\end{array}$ & $\begin{array}{l}0.167 * * * \\
(0.00970)\end{array}$ \\
\hline $\begin{array}{l}\text { potential } \\
\text { experience }^{3}\end{array}$ & $\begin{array}{l}0.0616 * * * \\
(0.00128)\end{array}$ & $\begin{array}{l}0.0282 * * * \\
(0.00121)\end{array}$ & $\begin{array}{l}0.0605 * * * \\
(0.00229)\end{array}$ & $\begin{array}{l}0.0551 * * * \\
(0.00429)\end{array}$ & $\begin{array}{l}0.0461 * * * \\
(0.00181)\end{array}$ & $\begin{array}{l}-0.0598^{* * *} \\
(0.00267)\end{array}$ \\
\hline $\begin{array}{l}\text { potential } \\
\text { experience }^{4}\end{array}$ & $\begin{array}{l}-0.00475 * * * \\
(0.000125)\end{array}$ & $\begin{array}{l}-0.00169 * * * \\
(0.000114)\end{array}$ & $\begin{array}{l}-0.00456 * * * \\
(0.000221)\end{array}$ & $\begin{array}{l}-0.00412 * * * \\
(0.000414)\end{array}$ & $\begin{array}{l}-0.00351 * * * \\
(0.000168)\end{array}$ & $\begin{array}{l}0.00523 * * * \\
(0.000252)\end{array}$ \\
\hline $\begin{array}{l}\text { dummy } \\
\text { intermediate } \\
\text { level of } \\
\text { education }\end{array}$ & $\begin{array}{l}0.0944 * * * \\
(0.000837)\end{array}$ & $\begin{array}{l}0.0661^{* * *} \\
(0.000992)\end{array}$ & $\begin{array}{l}0.105^{* * *} \\
(0.00176)\end{array}$ & $\begin{array}{l}0.112 * * * \\
(0.00260)\end{array}$ & $\begin{array}{l}0.0531^{* * *} \\
(0.00142)\end{array}$ & $\begin{array}{l}0.107^{* * *} \\
(0.00259)\end{array}$ \\
\hline $\begin{array}{l}\text { dummy high } \\
\text { level of } \\
\text { education }\end{array}$ & $\begin{array}{l}0.392 * * * \\
(0.00126)\end{array}$ & $\begin{array}{l}0.256^{* * *} \\
(0.00111)\end{array}$ & $\begin{array}{l}0.417 * * * \\
(0.00214)\end{array}$ & $\begin{array}{l}0.473 * * * \\
(0.00455)\end{array}$ & $\begin{array}{l}0.216 * * * \\
(0.00184)\end{array}$ & $\begin{array}{l}0.261 * * * \\
(0.00236)\end{array}$ \\
\hline d_DP_2008 & $\begin{array}{l}-0.0000111 \\
(0.000130)\end{array}$ & $\begin{array}{l}-0.00677^{* * *} \\
(0.000137)\end{array}$ & $\begin{array}{l}-0.00478 * * * \\
(0.000238)\end{array}$ & $\begin{array}{l}0.00876 * * * \\
(0.000377)\end{array}$ & $\begin{array}{l}-0.00414^{* * *} \\
(0.000201)\end{array}$ & $\begin{array}{l}-0.0413 * * * \\
(0.000315)\end{array}$ \\
\hline d_DP_2009 & $\begin{array}{l}-0.00799 * * * \\
(0.000117)\end{array}$ & $\begin{array}{l}-0.00259 * * * \\
(0.000126)\end{array}$ & $\begin{array}{l}-0.00616^{* * *} \\
(0.000218)\end{array}$ & $\begin{array}{l}-0.00536^{* * *} \\
(0.000338)\end{array}$ & $\begin{array}{l}-0.000304 \\
(0.000187)\end{array}$ & $\begin{array}{l}-0.0376^{* * *} \\
(0.000295)\end{array}$ \\
\hline
\end{tabular}




\begin{tabular}{|c|c|c|c|c|c|c|}
\hline d_DP_2010 & $\begin{array}{l}0.00689 * * * \\
(0.0000916)\end{array}$ & $\begin{array}{l}0.00608^{* * *} \\
(0.0000968)\end{array}$ & $\begin{array}{l}0.00870 * * * \\
(0.000169)\end{array}$ & $\begin{array}{l}-0.000595^{*} \\
(0.000271)\end{array}$ & $\begin{array}{l}0.00450 * * * \\
(0.000143)\end{array}$ & $\begin{array}{l}0.0476 * * * \\
(0.000229)\end{array}$ \\
\hline d_size_20_49 & $\begin{array}{l}0.00489 * * * \\
(0.000401)\end{array}$ & $\begin{array}{l}-0.00174 \\
(0.00173)\end{array}$ & $\begin{array}{l}0.000473 \\
(0.00144)\end{array}$ & $\begin{array}{l}0.0108 * * * \\
(0.00118)\end{array}$ & $\begin{array}{l}0.00157 \\
(0.00611)\end{array}$ & $\begin{array}{l}0.00465 \\
(0.0112)\end{array}$ \\
\hline d_size_50_99 & $\begin{array}{l}0.0105^{* * *} \\
(0.000496)\end{array}$ & $\begin{array}{l}-0.000199 \\
(0.00187)\end{array}$ & $\begin{array}{l}0.00851^{* * *} \\
(0.00153)\end{array}$ & $\begin{array}{l}0.0242^{* * *} \\
(0.00135)\end{array}$ & $\begin{array}{l}0.00939 \\
(0.00652)\end{array}$ & $\begin{array}{l}0.00553 \\
(0.0114)\end{array}$ \\
\hline d_size_100_199 & $\begin{array}{l}0.0144 * * * \\
(0.000556)\end{array}$ & $\begin{array}{l}0.000887 \\
(0.00187)\end{array}$ & $\begin{array}{l}0.0167 * * * \\
(0.00158)\end{array}$ & $\begin{array}{l}0.0230 * * * \\
(0.00148)\end{array}$ & $\begin{array}{l}-0.00428 \\
(0.00624)\end{array}$ & $\begin{array}{l}-0.00181 \\
(0.0114)\end{array}$ \\
\hline d_size_200_499 & $\begin{array}{l}0.0193 * * * \\
(0.000613)\end{array}$ & $\begin{array}{l}-0.000208 \\
(0.00187)\end{array}$ & $\begin{array}{l}0.0224 * * * \\
(0.00162)\end{array}$ & $\begin{array}{l}0.0333^{* * *} \\
(0.00162)\end{array}$ & $\begin{array}{l}-0.0104 \\
(0.00648)\end{array}$ & $\begin{array}{l}-0.00393 \\
(0.0114)\end{array}$ \\
\hline d_size_500+ & $\begin{array}{l}0.0237^{* * *} \\
(0.000671)\end{array}$ & $\begin{array}{l}0.00227 \\
(0.00188)\end{array}$ & $\begin{array}{l}0.0349 * * * \\
(0.00173)\end{array}$ & $\begin{array}{l}0.0285^{* * *} \\
(0.00171)\end{array}$ & $\begin{array}{l}-0.0239 * * * \\
(0.00645)\end{array}$ & $\begin{array}{l}-0.0112 \\
(0.0114)\end{array}$ \\
\hline cohort_46_50 & $\begin{array}{l}-0.00626 \\
(0.00507)\end{array}$ & $\begin{array}{l}0.106 * * * \\
(0.00451)\end{array}$ & $\begin{array}{l}-0.0133 \\
(0.0104)\end{array}$ & $\begin{array}{l}-0.0186 \\
(0.0111)\end{array}$ & $\begin{array}{l}-0.0740 * * * \\
(0.00924)\end{array}$ & $\begin{array}{l}0.124 * * * \\
(0.00982)\end{array}$ \\
\hline cohort_51_55 & $\begin{array}{l}0.00142 \\
(0.00512)\end{array}$ & $\begin{array}{l}0.152 * * * \\
(0.00450)\end{array}$ & $\begin{array}{l}0.0407 * * * \\
(0.0105)\end{array}$ & $\begin{array}{l}-0.0222 \\
(0.0115)\end{array}$ & $\begin{array}{l}-0.0991 * * * \\
(0.00907)\end{array}$ & $\begin{array}{l}0.245^{* * *} \\
(0.00982)\end{array}$ \\
\hline cohort_56_60 & $\begin{array}{l}0.0316 * * * \\
(0.00516)\end{array}$ & $\begin{array}{l}0.149 * * * \\
(0.00457)\end{array}$ & $\begin{array}{l}0.114 * * * \\
(0.0105)\end{array}$ & $\begin{array}{l}-0.00825 \\
(0.0118)\end{array}$ & $\begin{array}{l}-0.110^{* * *} \\
(0.00909)\end{array}$ & $\begin{array}{l}0.332 * * * \\
(0.0100)\end{array}$ \\
\hline cohort_61_65 & $\begin{array}{l}0.0709 * * * \\
(0.00518)\end{array}$ & $\begin{array}{l}0.140 * * * \\
(0.00466)\end{array}$ & $\begin{array}{l}0.185^{* * *} \\
(0.0105)\end{array}$ & $\begin{array}{l}0.0121 \\
(0.0120)\end{array}$ & $\begin{array}{l}-0.113 * * * \\
(0.00916)\end{array}$ & $\begin{array}{l}0.436 * * * \\
(0.0104)\end{array}$ \\
\hline cohort_66_70 & $\begin{array}{l}0.0846 * * * \\
(0.00522)\end{array}$ & $\begin{array}{l}0.149 * * * \\
(0.00482)\end{array}$ & $\begin{array}{l}0.221 * * * \\
(0.0106)\end{array}$ & $\begin{array}{l}0.0251^{*} \\
(0.0122)\end{array}$ & $\begin{array}{l}-0.122 * * * \\
(0.00936)\end{array}$ & $\begin{array}{l}0.621 * * * \\
(0.0110)\end{array}$ \\
\hline cohort_71_75 & $\begin{array}{l}0.0944 * * * \\
(0.00529)\end{array}$ & $\begin{array}{l}0.192 * * * \\
(0.00504)\end{array}$ & $\begin{array}{l}0.260 * * * \\
(0.0107)\end{array}$ & $\begin{array}{l}0.0298 * \\
(0.0126)\end{array}$ & $\begin{array}{l}-0.111^{* * *} \\
(0.00955)\end{array}$ & $\begin{array}{l}0.837^{* * *} \\
(0.0115)\end{array}$ \\
\hline cohort_76_80 & $\begin{array}{l}0.115^{* * *} \\
(0.00540)\end{array}$ & $\begin{array}{l}0.246^{* * *} \\
(0.00529)\end{array}$ & $\begin{array}{l}0.312^{* * *} \\
(0.0109)\end{array}$ & $\begin{array}{l}0.0538^{* * *} \\
(0.0131)\end{array}$ & $\begin{array}{l}-0.0978 * * * \\
(0.00987)\end{array}$ & $\begin{array}{l}1.044 * * * \\
(0.0120)\end{array}$ \\
\hline cohort_81_85 & $\begin{array}{l}0.151^{* * *} \\
(0.00552)\end{array}$ & $\begin{array}{l}0.273 * * * \\
(0.00563)\end{array}$ & $\begin{array}{l}0.385^{* * *} \\
(0.0112)\end{array}$ & $\begin{array}{l}0.0938^{* * *} \\
(0.0136)\end{array}$ & $\begin{array}{l}-0.0838^{* * *} \\
(0.0106)\end{array}$ & $\begin{array}{l}1.194 * * * \\
(0.0131)\end{array}$ \\
\hline cohort_86_87 & $\begin{array}{l}0.185^{* * *} \\
(0.00609)\end{array}$ & $\begin{array}{l}0.280 * * * \\
(0.00803)\end{array}$ & $\begin{array}{l}0.452^{* * *} \\
(0.0138)\end{array}$ & $\begin{array}{l}0.116^{* * *} \\
(0.0150)\end{array}$ & $\begin{array}{l}-0.0722^{* * *} \\
(0.0187)\end{array}$ & $\begin{array}{l}1.306^{* * *} \\
(0.0241)\end{array}$ \\
\hline
\end{tabular}




$\begin{array}{lllllll}\text { Observations } & 1782966 & 1437157 & 468007 & 305964 & 328892 & 130120 \\ \text { Groups } & 676493 & 416450 & 152922 & 120952 & 83676 & 40746 \\ \text { Sigma_u } & .2587098 & .3029131 & .2906719 & .2245666 & .3075842 & .2599716 \\ \text { Sigma_e } & .0785262 & .0785334 & .0761724 & .0989644 & .0561318 & .0537179 \\ \text { R2 within } & .1002334 & .102531 & .1611854 & .0295818 & .1786376 & .6325353 \\ \text { R2 overall } & .2910591 & .1795977 & .2078528 & .1107965 & .2128613 & .1649314 \\ \text { R2 between } & .3274646 & .2018834 & .2310616 & .1193921 & .2341895 & .1684003\end{array}$

Standard errors in parentheses, $* p<0.05 * * p<0.01 * * * p<0.001$

Note: Based on random effects regressions, with tenure instrumented with the deviation between tenure and the individual job average of tenure, and potential experience is instrumented likewise. Control variables taken into account are two dummy variables for the level of education, three time dummies (we use the transformation proposed by Deaton and Paxson, 1994, where all time effects add up to zero: due to these transformations, there are no real time exects), cohortdummies (year of birth 1946-1950, ..., 1981-1985, and 1986-1987), a dummy for fulltime contracts, five dummies representing the size class of the firm as well as 22 dummies (not presented) for the CLA sectors of industry and a constant. 
Table C3 Regressions explaining the indicators

\begin{tabular}{|c|c|c|c|}
\hline & $\begin{array}{l}\text { Private sector } \\
\mathrm{I}^{=}\end{array}$ & $\begin{array}{l}\text { Public sector } \\
\mathrm{I}^{=}\end{array}$ & $\begin{array}{l}\text { Private sector } \\
\mathrm{I}^{+}\end{array}$ \\
\hline ten & $\begin{array}{l}0.00799 * * * \\
(0.000401)\end{array}$ & $\begin{array}{l}0.0129 * * * \\
(0.000449)\end{array}$ & $\begin{array}{l}0.0000690 \\
(0.000217)\end{array}$ \\
\hline ten2 & $\begin{array}{l}-0.0578 * * * \\
(0.00454)\end{array}$ & $\begin{array}{l}-0.0547^{* * *} \\
(0.00479)\end{array}$ & $\begin{array}{l}0.0104 * * * \\
(0.00275)\end{array}$ \\
\hline ten3 & $\begin{array}{l}0.0176 * * * \\
(0.00183)\end{array}$ & $\begin{array}{l}0.0119 * * * \\
(0.00182)\end{array}$ & $\begin{array}{l}-0.00496 * * * \\
(0.00120)\end{array}$ \\
\hline ten4 & $\begin{array}{l}-0.00174 * * * \\
(0.000236)\end{array}$ & $\begin{array}{l}-0.00112^{* * *} \\
(0.000225)\end{array}$ & $\begin{array}{l}0.000639 * * * \\
(0.000162)\end{array}$ \\
\hline leeftijd & $\begin{array}{l}0.00395 * * * \\
(0.000255)\end{array}$ & $\begin{array}{l}0.0162^{* * *} \\
(0.000304)\end{array}$ & $\begin{array}{l}0.0252^{* * *} \\
(0.000203)\end{array}$ \\
\hline leeftijd2 & $\begin{array}{l}-0.0000383^{* * *} \\
(0.00000295)\end{array}$ & $\begin{array}{c}-0.000108 * * * \\
(0.00000338)\end{array}$ & $\begin{array}{l}-0.000232 * * * \\
(0.00000240)\end{array}$ \\
\hline doplk|2 & $\begin{array}{l}-0.0234^{* * *} \\
(0.00103)\end{array}$ & $\begin{array}{l}-0.00451 * * * \\
(0.00110)\end{array}$ & $\begin{array}{l}0.0374 * * * \\
(0.000899)\end{array}$ \\
\hline doplkl3 & $\begin{array}{l}-0.123 * * * \\
(0.00132)\end{array}$ & $\begin{array}{l}-0.0109 * * * \\
(0.000886)\end{array}$ & $\begin{array}{l}0.252 * * * \\
(0.00124)\end{array}$ \\
\hline Observations & 1524927 & 1336327 & 2380953 \\
\hline Groups & 585358 & 438227 & 860736 \\
\hline R2 within & .0047326 & .0333161 & .0209588 \\
\hline R2 overall & .0455022 & .2037117 & .1187407 \\
\hline R2 between & .0623667 & .3050586 & .1256767 \\
\hline
\end{tabular}

Standard errors in parentheses; ${ }^{*} p<0.05,{ }^{*} p<0.01,{ }^{* * *} p<0.001$

${ }^{1)}$ Indicator I= is the indicator of the contractual wages being at the wage ceiling of a wage scale and combines the information of II and I2 (Indicator II reflecting the proximity of the individual contractual wage to the wage ceiling of a wage scale, indicator 12 reflecting the proximity of contractual wage growth to collectively-agreed wage growth). Indicator I+ is the indicator of the contractual wages exceeding the wage ceiling of the highest wage scale.

The effects of age and tenure are obtained from random effects regressions containing age and age ${ }^{2}$ and tenure, tenure ${ }^{2}$, tenure ${ }^{3}$ and tenure ${ }^{4}$. The variables representing the level of education are defined as d_educ_int = dummy for an intermediate level of education and d_educ_high=dummy for a high level of education. Included as control variables are four year variables, a dummy for full- 
time contracts, five dummies representing the size class of the firm, as well as dummies for the CLA sectors of industry.

The cumulative effects of age and tenure on the indicators, according to the estimated coefficients, can be found in Table 7. 
Table C4 Regressions for log real hourly gross wage and resulting wage profiles over tenure and potential experience, for private and public sector CLA's as a group.

\begin{tabular}{|c|c|c|c|c|c|}
\hline & Private sector & $\begin{array}{l}\text { Private sector } \\
\text { excl. jobs } \\
\text { exceeding } \\
\text { highest wage } \\
\text { scale ceiling } \\
\text { in any year }\end{array}$ & Private sector & Public sector & $\begin{array}{l}\text { Public sector } \\
\text { excl. jobs } \\
\text { exceeding } \\
\text { highest wage } \\
\text { scale ceiling } \\
\text { in any year }\end{array}$ \\
\hline \multirow[t]{2}{*}{ tenure } & $0.00266^{* * *}$ & $0.00282^{* * *}$ & $0.00268^{* * *}$ & $0.00540^{* * *}$ & $0.00621 * * *$ \\
\hline & $(0.000207)$ & $(0.000223)$ & $(0.000592)$ & $(0.000209)$ & $(0.000210)$ \\
\hline \multirow[t]{2}{*}{ tenure $^{2}$} & $-0.0215^{* * *}$ & $-0.0230 * * *$ & $-0.0200 * * *$ & $-0.0358 * * *$ & $-0.0422 * * *$ \\
\hline & $(0.00144)$ & $(0.00157)$ & $(0.00517)$ & $(0.00118)$ & $(0.00116)$ \\
\hline \multirow[t]{2}{*}{ tenure ${ }^{3}$} & $0.00448 * * *$ & $0.00480 * * *$ & $0.00391 * * *$ & $0.00237 * * *$ & $0.00380 * * *$ \\
\hline & $(0.000288)$ & $(0.000318)$ & $(0.00108)$ & $(0.000207)$ & $(0.000202)$ \\
\hline \multirow[t]{2}{*}{ pot. experience } & $0.0781 * * *$ & $0.0741 * * *$ & $0.0787^{* * *}$ & $0.0693 * * *$ & $0.0724 * * *$ \\
\hline & $(0.00100)$ & $(0.00102)$ & $(0.00110)$ & $(0.000795)$ & $(0.000785)$ \\
\hline \multirow[t]{2}{*}{ pot. experience ${ }^{2}$} & $-0.286 * * *$ & $-0.287^{* * *}$ & $-0.283^{* * *}$ & $-0.165^{* * *}$ & $-0.199 * * *$ \\
\hline & $(0.00699)$ & $(0.00726)$ & $(0.00800)$ & $(0.00532)$ & $(0.00524)$ \\
\hline \multirow[t]{2}{*}{ pot. experience ${ }^{3}$} & $0.0519 * * *$ & $0.0523 * * *$ & $0.0512 * * *$ & $0.0183 * * *$ & $0.0273 * * *$ \\
\hline & (0.00198) & (0.00209) & $(0.00235)$ & $(0.00145)$ & $(0.00143)$ \\
\hline \multirow[t]{2}{*}{ pot. experience ${ }^{4}$} & $-0.00376 * * *$ & $-0.00368 * * *$ & $-0.00369 * * *$ & $-0.000651 * * *$ & $-0.00144 * * *$ \\
\hline & $(0.000194)$ & $(0.000206)$ & $(0.000233)$ & $(0.000136)$ & $(0.000134)$ \\
\hline \multirow[t]{2}{*}{ ten $*$ leave $t+1$} & & & -0.000132 & & \\
\hline & & & $(0.000423)$ & & \\
\hline \multirow[t]{2}{*}{ ten $2 *$ leave $t+1$} & & & 0.000261 & & \\
\hline & & & (0.00459) & & \\
\hline \multirow[t]{2}{*}{ ten $3 *$ leave $t+1$} & & & 0.000133 & & \\
\hline & & & $(0.00103)$ & & \\
\hline \multirow[t]{2}{*}{ dummy leave $t+1$} & & & $-0.00420 * *$ & & \\
\hline & & & $(0.00143)$ & & \\
\hline Observations & 1782477 & 1280196 & 1782412 & 1431683 & 1277680 \\
\hline Groups & 676275 & 505043 & 676262 & 415849 & 368270 \\
\hline Sigma_u & 0.2605 & .1680 & 0.2777 & .3129 & .3751 \\
\hline
\end{tabular}




$\begin{array}{llllll}\text { Sigma_e } & .1217 & .1075 & 0.1217 & .0931 & .0911 \\ \text { R2 within } & .0372 & .0441 & 0.0371 & .0840 & .0805 \\ \text { R2 overall } & .2252 & .2124 & 0.2251 & .1649 & .1689 \\ \text { R2 between } & .2675 & .2687 & 0.2675 & .1757 & .1760\end{array}$

Cumulative effects on log real hourly gross wage:

Years of potential experience:

\begin{tabular}{|c|c|c|c|c|c|}
\hline 10 & 0,54 & 0,5 & 0,55 & 0,55 & 0,55 \\
\hline 20 & 0,77 & 0,69 & 0,79 & 0,86 & 0,85 \\
\hline 30 & 0,87 & 0,75 & 0,9 & 1,04 & 1,00 \\
\hline 40 & 0,91 & 0,77 & 0,95 & 1,15 & 9 \\
\hline
\end{tabular}

Years of tenure:

\begin{tabular}{rrrrrr}
10 & 0,01 & 0,01 & 0,01 & 0,02 & 0,02 \\
20 & 0,00 & 0,00 & 0,00 & $-0,02$ & $-0,01$ \\
30 & 0,01 & 0,01 & 0,01 & $-0,1$ & $-0,09$ \\
40 & 0,05 & 0,05 & 0,04 & $-0,2$ & $-0,18$ \\
\hline
\end{tabular}

Standard errors in parentheses

$* \mathrm{p}<0.05, * * \mathrm{p}<0.01, * * * \mathrm{p}<0.001$

Note: Based on random effects regressions, with tenure instrumented with the deviation between tenure and the individual job average of tenure, and potential experience instrumented likewise. Control variables taken into account are two dummy variables for the level of education, three year dummies (a la Altonji \& Paxton), cohort dummies (year of birth: 1946-1950, ..., 1981-1985, and 1986-1987), a dummy for full-time contracts, five dummies representing the size class of the firm, as well as 22 dummies (not presented) for the CLA sectors of industry and a constant. "leave $t+1$ " is an attrition dummy, indicating that the worker is not present anymore in the dataset in year $\mathrm{t}+1$. 


\section{References}

Abraham, K.G. and H.S. Farbe, 1987, Job Duration, Seniority, and Earnings, The American Economic Review, 77(3), pp. 278-297.

Altonji, J.G. and R.A. Shakotko, 1987, Do wages rise with Job Seniority?, The Review of Economic Studies, Vol. 54, pp. 437-459.

Altonji, J. and N. Williams, 2005, Do wages rise with job seniority? A reassessment., Industrial and Labour Relations Review, Vol. 58(3), pp. 370-397.

Börsch-Supan, A. and M. Weiss, 2008, Productivity and age: Evidence from work teams at the assembly line, MEA Discussion Paper, 148-07.

Buchinsky, M., D. Fougère, F. Kramarz and R. Tchernis, 2010, Interfirm mobility, wages, and the returns to seniority and experience in the US, The Review of Economic Studies, Vol. 77, pp. 972-1001.

Cardoso, A. and P. Portugal, 2005, Contractual Wages and the Wage Cushion under Different Bargaining Settings, Journal of Labor Economics, Vol. 23(4), pp. 875-902.

Conen, W., H. van Dalen and K. Henkens, 2012, Ageing and Employers’ Perceptions of Labour Costs and Productivity, International Journal of Manpower, Vol. 33(6), pp. 629-647.

Deaton, A. and C. Paxson, 1994, Intertemporal Choice and Inequality, Journal of Political Economy, Vol. 102(3), pp. 437-467.

Deelen, A., 2012, Wage-Tenure Profiles and Mobility, De Economist, Vol. 160(2), pp. 141155.

Dustmann, C., and C. Meghir, 2005, Wages, experience and seniority, Review of Economic Studies,Vol. 72, pp. 77-108.

Euwals, R., R. de Mooij and D. van Vuuren, 2009, Rethinking Retirement, CPB Book 80. 
Fuss, C., 2009, What is the most flexible component of wage bill adjustment? Evidence from Belgium, Labour Economics, Vol. 16, pp. 320-329.

Jung, S., and C. Schnabel, 2011, Paying More than Necessary? The Wage Cushion in Germany, Labour, Vol 25(2), pp. 182-197.

OECD, 2006, Live Longer, Work Longer, OECD, Paris.

OECD, 2014, Ageing and Employment Policies: Netherlands 2014, OECD, Paris.

Van Ours, J. and L. Stoeldraijer, 2011, Age, Wage and Productivity in Dutch Manufacturing, De Economist, Vol. 159, pp. 113-137.

Zwick, T., 2012, Consequences of Seniority Wages on the Employment Structure, Industrial and Labor Relations Review, Vol. 65(1), pp. 108-125. 